\title{
Renewable Energy in the Pomerania Voivodeship-Institutional, Economic, Environmental and Physical Aspects in Light of EU Energy Transformation
}

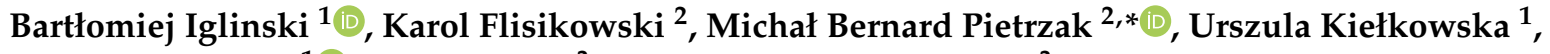 \\ Mateusz Skrzatek ${ }^{1}$ (D) Anas Zyadin ${ }^{3}$ and Karthikeyan Natarajan ${ }^{3}$ \\ 1 Faculty of Chemistry, Nicolaus Copernicus University in Toruń, Gagarina 11, 87-100 Toruń, Poland; \\ iglinski@chem.umk.pl (B.I.); ulak@chem.umk.pl (U.K.); teusz@doktorant.umk.pl (M.S.) \\ 2 Faculty of Management and Economics, Gdańsk University of Technology, Gabriela Narutowicza 11/12, \\ 80-233 Gdańsk, Poland; kfi@zie.pg.gda.pl \\ 3 School of Forest Sciences, University of Eastern Finland, P.O. Box 111, 801014 Joensuu, Finland; \\ anas.zyadin@uef.fi (A.Z.); kaartheekeyan@rediff.com (K.N.) \\ * Correspondence: michal.pietrzak@zie.pg.gda.pl
}

Citation: Iglinski, B.; Flisikowski, K.; Pietrzak, M.B.; Kiełkowska, U.; Skrzatek, M.; Zyadin, A.; Natarajan, K. Renewable Energy in the Pomerania VoivodeshipInstitutional, Economic, Environmental and Physical Aspects in Light of EU Energy Transformation. Energies 2021, 14, 8221. https:// doi.org/10.3390/en14248221

Academic Editors: Adrian Ilinca and Dalia Štreimikienè

Received: 21 October 2021

Accepted: 3 December 2021

Published: 7 December 2021

Publisher's Note: MDPI stays neutral with regard to jurisdictional claims in published maps and institutional affiliations.

Copyright: (C) 2021 by the authors Licensee MDPI, Basel, Switzerland. This article is an open access article distributed under the terms and conditions of the Creative Commons Attribution (CC BY) license (https:/ / creativecommons.org/licenses/by/ $4.0 /)$.

\begin{abstract}
In the era of globalization and rapid economic growth, affecting most world economies, increased production and consumption are leading to higher levels of energy production and consumption. The growing demand for energy means that energy resources from conventional sources are not sufficient; moreover, its production generates high costs and contributes to the emission of greenhouse gases and waste. In view of the above, many countries have opted to implement an energy transformation. The energy transition allows the transition from an energy system based on conventional fuels to an energy system based mainly on renewable energy (RE) and low-emission sources. In the EU, the development of a "green economy" has become a strategic goal in the fight against climate change. The development of RE offers the possibility to improve the energy security of a given country and the entire EU. New, innovative technologies of RE also increase the attractiveness and competitiveness of the economies of the Member States. In line with the EU strategy, the activities carried out aim to achieve a situation in which, in 2050, the activities of economies will not endanger the environment. The main purpose of this article was the assessment of the RE sector in the Pomerania region in the context of energy transformation. To achieve this goal, PEST analysis regarding the functioning of the RE sector in the selected Polish region was used and the potential of the RE sector was determined using GIS tools on the basis of physical conditions. The article presents the research hypothesis that the RE sector within the Pomerania Voivodeship possesses appropriate energy potential, which will allow this Voivodeship to become an energy self-sufficient region based on the use of these energy sources (according to EU strategy). The implementation of the goal set in the article allowed for the verification of the research hypothesis, where the determined energy potential from the RE sector would cover the Voivodeship's needs due to the use of electricity and heat. The conducted research shows that the RE sector in these regions has high energy potential to meet the criteria outlined in EU legal documents and to implement them successfully within the intended period.
\end{abstract}

Keywords: renewable energy; energy transition; decarbonization strategy; energy potential; PEST analysis; Pomerania Voivodeship

\section{Introduction}

In the current era of globalization and economic growth, increased production and consumption leads to higher energy production levels. Energy usage plays a substantial role in globalization processes, thus leading to unsustainability through the use of natural resources on a large scale [1,2]. The continuous increase in energy demand means 
that the most frequently used energy sources are no longer sufficient. Energy from nonrenewable sources has become more expensive, harmful for the environment, and thus less profitable $[3,4]$. This situation creates the perfect conditions for an intensive energy transformation in developing countries $[5,6]$. The shift to a "green economy" has become a global phenomenon and is based on the effective consumption of energy and the gradual replacement of fossil fuels with clean energy sources [7]. This process is understood as a transformation from the current energy system using fossil fuels to an energy system based mainly on low-emission and renewable sources. It includes the gradual replacement of exhaustible hydrocarbons and uranium fuel by renewable energy (RE) in almost all sectors of the economy (transport, industry, energy, heating, construction, agriculture, etc.).

For the EU countries, the transformation of the energy system has become an important strategic goal, the implementation of which will allow for increased energy security and the improved investment attractiveness of the economies of the Member States [1,2]. This transformation, however, is being processed through the institutional system first [8-11]. The future structure of electricity generation is determined in the context of trends in the EU climate policies [12]. Poland, which entered the EU in 2004, adapted and integrated its institutional model [13]. New member states such as Poland have made a commitment to reduce the emission of greenhouse gases by ratifying the Kyoto Protocol and by participating in the climate policy of the EU [14]. The EU is fighting climate change through very ambitious policies. Currently, the EU is on track to reduce gas emissions by at least $55 \%$ by 2030 ("2030 Climate Target Plan"). By 2050, Europe aims to become the first climate-neutral continent ("European Climate Law"). These are the short-term goals, and the long-term aim within Europe is to become a climate-neutral economy with net-zero greenhouse gas emissions. Among many key targets for 2030, the most important are as follows: at least $40 \%$ cuts in greenhouse gas emissions (from 1990 levels), at least $32 \%$ share for RE, and at least $32.5 \%$ improvement in energy efficiency. The 2030 package includes a higher renewables target and new rules to support the expansion of renewables. The EU increased its greenhouse gases emissions reduction target for 2030 from $40 \%$ to $55 \%$ and the RE target from $32 \%$ to $40 \%$. This means that the EU will need $451 \mathrm{GW}$ of wind power capacity by 2030, an increase from the current value of $180 \mathrm{GW}$. The long-term strategy is in line with the EU's commitment to global climate action under the European Green Deal and Paris Agreement (a global framework to avoid dangerous climate change by limiting global warming). Both of these acts seek to address climate change and environmental degradation. From a long-term perspective, the EU is to be transformed into a modern, resource-efficient, and competitive economy, ensuring no net emissions of greenhouse gases by 2050, economic growth decoupled from resource use, and no person and no place left behind.

European integration processes, amplified by overall globalization in the background, have led to improved socio-economic and institutional situations in many states [15-21]. With time, the improved condition of the economies allowed the introduction of new, innovative RE projects [22-26]. Besides RE projects, since the early 2000s, many private investors and businesses have become the additional "engine" supporting the rapid growth of this market in Eastern Europe [26,27]. EU programs are usually organized on either commercial or hybrid models, subsidized by the government or EU (with national or regional range). Thanks to such programs, and their national and regional institutions, new consumption attitudes in the field of RE have been popularized, and many new jobs have been created [28-30]. All these actions favor change in the structure of the labor market in Poland and in the EU in general - we can observe increased employment mobility [31-38]. The RE labor sector in Poland is one in which employment has been increasing for the last two decades [39-41]. It is expected that, during the COVID-19 pandemic, the political and economic environment may not support the short-term expansion of the RE sector, but, from a long-term perspective, positive trends are forecasted [42,43]. Moreover, further growth in total energy consumption is predicted, representing a huge challenge for the RE market as well [44-46]. 
It should also be emphasized that the new EU climate policies and the rapid development of innovative RE technologies are implemented at the level of both countries and regions [47-49]. The RE market transformation should be based on the diversification of energy sources-they are not evenly geographically accessible [50]. Taking into account all of the aforementioned facts, we conclude that it is worth analyzing the regional potential first (at the Voivodeship level) and then evaluating individual sources of RE in light of EU requirements.

If we consider the energy sector in Poland, this country is only at the beginning of the energy transformation - most of the region's energy is still obtained from hard coal and lignite. At the end of September 2021, the installed capacity in all generation sources in Poland amounted to 53,274.6 MW. In conventional power plants, the country has 36,585.1 MW, and in RES installations, 15,276 MW. Only in September, 15,216.4 GWh of energy was produced in Poland, of which 12,775.4 GWh was generated by the conventional segment of the energy sector, and RES installations represented 2385.4 GWh [51].

The Pomerania Voivodeship is located is located in the northern part of the country and borders the Baltic Sea. It includes the following geographical units: Pobrzeże Południowobałtyckie, Lakeland Pomorskie, and Żuławy. Its total area is $18,310 \mathrm{~km}^{2}$. The population of the Voivodeship in 2019 amounted to 2,343,928 people and shows an upward trend. The population density was 128 people $/ \mathrm{km}^{2}$. Most of the population lives in urbanized areas (63.5\%) [52].

For these reasons, the aim of this study was to examine the current state, potential, and development prospects of the RE sector in the Pomerania (Pomorskie in Polish) Voivodeship in the context of energy transformation. To achieve this goal, PEST analysis regarding the development of RE in the Pomerania Voivodeship was used and the potential of the RE sector was determined using GIS tools on the basis of physical conditions. The article presents the research hypothesis that the Pomerania Voivodeship has an appropriate level of RE potential, which will allow this Voivodeship to become an energy self-sufficient region in line with the EU's short- and long-term strategy based on the use of RE. The implementation of the goal set in the article allowed for the verification of the research hypothesis regarding whether the potential amount of RE electricity would cover the Voivodeship's needs. Moreover, the results obtained confirm that the requirements of both the 2030 and $2050 \mathrm{EU}$ acts are expected to be satisfied in terms of RE and the RE market's transformation.

\section{Assessment of Development Potential of RE in Pomerania Voivodeship-PEST Analysis}

For the assessment of the potential of the Pomeranian Voivodeship in light of the energy transformation and development of RE, we use PEST analysis. PEST analysis belongs to the group of methods used to study the macro-environment.

The main elements of the macro-environment are (Figure 1) [53]:

- political: including political stability, RE policy, legislative environment;

- economic: including economic situation in the world and in the Pomerania Voivodeship, the labor market, interest rates;

- $\quad$ social: including demography, knowledge about RE, structure of availability of personnel and human resources;

- technological: including the innovativeness of the RE sector, transfer of technologies and techniques (Figure 1). 


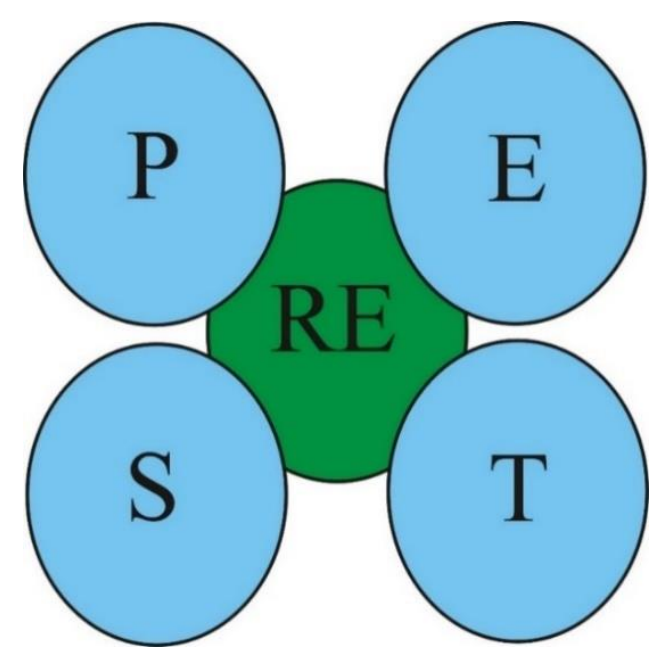

Figure 1. Utilized PEST analysis factors for RE macro-environment: P-political, E-economic, S-social, T-technological (author's own work).

In the presented work, it was considered advisable to subject the diagnosed factors to scoring, depending on the extent to which they support the RE sector. In the utilized scale ranging from 1 to 5 , depending on the degree of their support for the development of renewable energy, individual points were assigned as follows:

- 1 -very unconducive factor;

- 2-unconducive factor;

- 3-factor without influence;

- 4-contributing factor;

- 5-a very conducive factor.

At the same time, a formula for averaging the assessments of selected factors was adopted, assuming that this impact on its development means:

- below 2.00 points-the macro-environment is very hostile;

- $\quad$ 2.00-2.99 points-hostile macroenvironment;

- 3.00-3.49-neutral macroenvironment;

- $\quad 3.50-4.49$-friendly macro-environment;

- $\quad 4.50-5.00$ - very friendly macroenvironment [53].

This PEST analysis was performed in line with the available literature as well as the current political, economic, social, and technological situation in the Pomerania region and Poland. The weights were counted from 1.00 to 5.00. To determine the weights, a team of experts was appointed, consisting of individuals from the Nicolaus Copernicus University, Gdańsk University of Technology, and the University of East Finland. In particular, the authors performed the PEST analysis using the weighting performed by a panel of experts in the fields of Economics, Chemistry, Biology, and Geography.

\subsection{PEST Analysis-Political Environment}

Table 1 contains the political determinants of the RE in the Pomerania region. The political factors of renewable energy sources in the Pomeranian Voivodeship generally result from the system and the political system in which it operates. 
Table 1. The political environment of RE sources in the Pomerania Voivodeship (author's own work).

\begin{tabular}{ccc}
\hline & Factor & Strengthening the RE Sector \\
\hline 1. & Political system and its stability & 3.50 \\
2. & Public administration system and its efficiency & 2.00 \\
3. & RE policy at the Voivodeship/state level & 3.00 \\
4. & Programs supporting the development of RE & 4.50 \\
5. & Documents on the use of the environment and & 4.00 \\
6. & GHG emissions & 1.00 \\
7. & A strong conventional energy lobby & 5.00 \\
\hline
\end{tabular}

The constitution law [54] states that Poland is a parliamentary republic and realizes the principles of independence and national sovereignty of a democratic state ruled by law. The current political system in the Republic of Poland can be considered relatively stable. The development of the research and science sphere, including RE, is positively influenced by a fairly friendly administrative order.

The administration in Poland is an integral part of the country, a vehicle of remembrance of the state's tradition and endowed with the privilege of legislative initiative. Moreover, the preamble to the Constitution of the Republic of Poland [52] defines a very important goal related to the need to improve the functioning of the public sector in the Republic of Poland. Despite many efforts, the public administration does not function efficiently in Poland-it is not conducive to the development of RE sources, which is often emphasized by the owners of RE installations.

As indicated by respondents in surveys [53-55], the policy in the field of RE at the state/Voivodeship level is not very conducive to the development of RE. The "Distance Act" [56] stopped the development of aeroenergy (wind energy) in Poland. The RE Act [57] is frequently amended, which discourages potential investors. For every $1 \mathrm{kWh}$ of energy introduced to the grid, the prosumer can receive only $0.8 \mathrm{kWh}$ of energy at any time.

The Polish energy policy, implemented until 2040, represents an opportunity for the development of RE in the Pomerania Voivodeship [58]. Poland's energy policy until 2040 places a strong emphasis on three main pillars. The first is a fair energy transition, the second is the construction of a parallel, emission-free energy system, and the third is good air quality.

When deciding to purchase/build an RE installation, it is worth using a subsidy/loan/ financial relief. First, it is necessary to check whether there are funds for RE in a given town, commune, poviat, or Voivodeship and whether there are funds for investment in the national program or the EU program. For example, the "My Electricity" program allows one to obtain funding for the building of small photovoltaic installations (between $2 \mathrm{~kW}$ and $10 \mathrm{~kW}$ ) in the form of a subsidy for up to $50 \%$ of the costs, but this is no more than PLN 5000 (in 2021, PLN 3000) for one project. Figure 2 shows the results of the "My Electricity 2" program [59]. The green color indicates the amount of co-financing granted to PV installation projects, while the black color indicates the installation power in a given Voivodeship $(\mathrm{kW})$. 


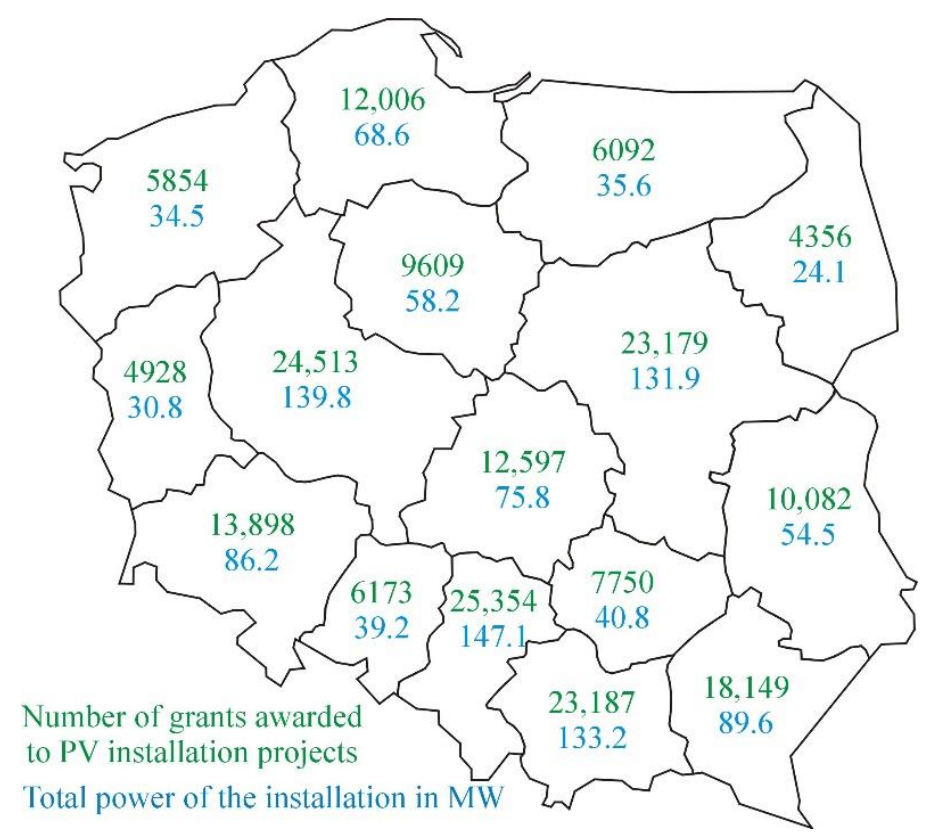

Figure 2. Results of the "My Electricity 2" program (own study from [59]).

In Poland, the Environmental Protection Law [60] describes legal regulations related to the use of the environment, including CHG emissions. According to the act, the principles of sustainable development constitute the basis for the preparation and updating of the national spatial development concept, Pomerania Voivodeship development strategies, and Voivodeship spatial development plans. The development of RE in the Pomerania Voivodeship/Poland is hindered by the strong lobby for conventional energy, mainly the coal lobby. Associated with mines, coal-fired power plants, and trade unions, they openly oppose the development of RE in Poland [55].

In order to ensure institutional "maturity" in Poland, this country is a member of the $\mathrm{EU}$ and other international organizations related to the law. Globalization processes positively influence the development of RE. This allows for open functioning in the European Research Area as part of the conducted research. This also allows for joint research projects and the free movement of employees between universities [55].

\subsection{PEST Analysis-Economic Environment}

Table 2 shows the economic factors of RE in the Pomerania region. In the case of EU Member States, Poland is characterized by economic growth. This was brought to a halt due to the COVID-19 pandemic. Figure 3 shows the dynamics of the volume and added value of Poland in the years 2016-2020 [61]. The world economy has practically recovered from the crisis that started in 2008 and is now struggling with the economic problems resulting from the pandemic. The prices of energy carriers remain at an average level; in October 2021, the price of crude oil was around USD 83-84/barrel [62], the price of hard coal was USD 233/Mg [63], and the price of natural gas was USD 5.30/million bt [64]. These prices are higher than 2 years ago [55], which means that energy from RE sources is becoming increasingly competitive in relation to energy from fossil fuels. 
Table 2. The economic factors of RE in the Pomerania Voivodeship (author's own work).

\begin{tabular}{ccc}
\hline & Factor & Strengthening the RE Sector \\
\hline 1. & Socio-economic development and economic growth & 3.50 \\
2. & $\begin{array}{r}\text { The economic situation in the world, world fuel and } \\
\text { energy prices, energy resources in the world }\end{array}$ & 3.50 \\
& Labor market (including in the RE sector), & 3.50 \\
3. & unemployment level & 2.00 \\
4. & Own funds for financing RE installations & 4.00 \\
5. & availability of loans and credit, interest rates, \\
6. & Economic support (auctions and green certificates) & 3.00 \\
7. & Investor activity, entrepreneurship, and innovation & 4.00 \\
8. & EU membership-globalization & 5.00 \\
\hline
\end{tabular}

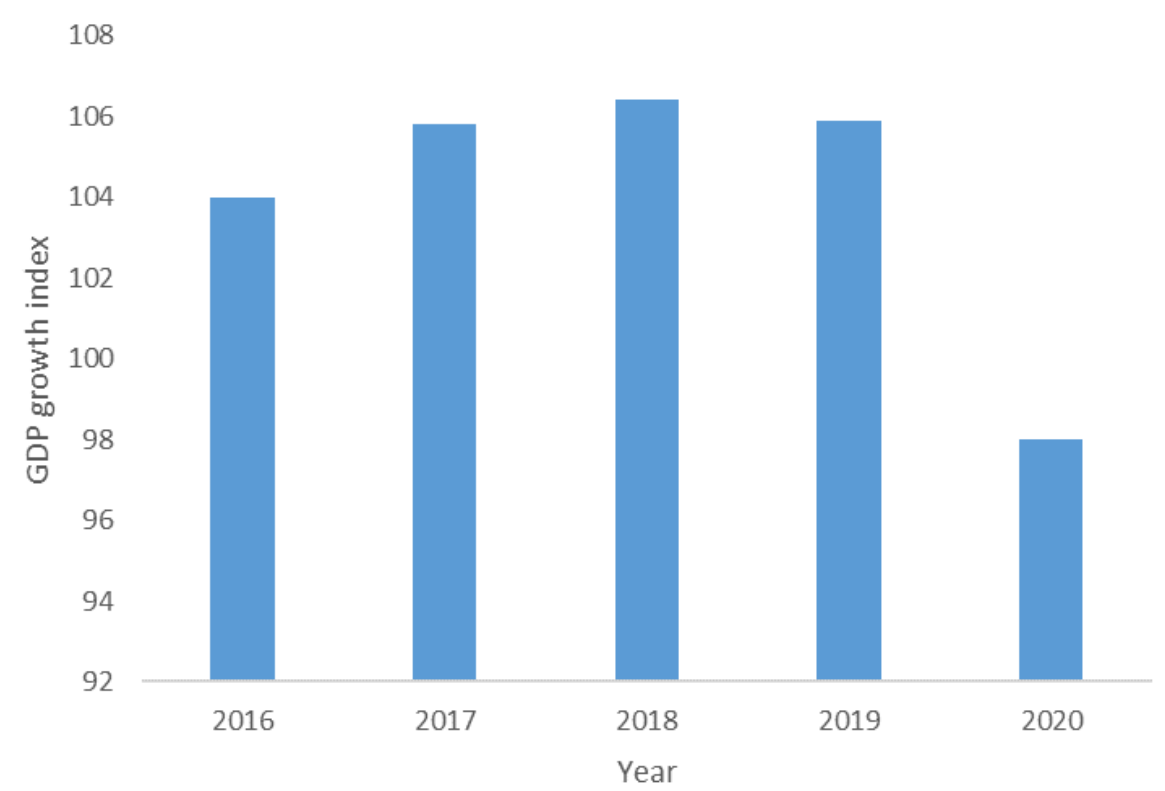

Figure 3. GDP growth index in the years 2016-2020 in Poland (own study from [59]).

An important element of the macro-environment of RE in the Pomeranian Voivodeship is the situation of the labor market: employment structure, unemployment rate, and population migrations. Official data [65] indicate that the unemployment rate in Poland at the end of August 2021 was $6.4 \%$ (5.6\% in the Pomerania Voivodeship). Moreover, rural areas with relatively high unemployment offer excellent conditions for the development of renewable energy sources. A $20 \%$ rate of unemployment, which was measured in 2004/2005, and accession to the EU resulted in intensified emigration processes in Poland and in the Pomeranian Voivodeship. Currently, over 2 million Poles live abroad. Inflation in Poland was declining until the outbreak of the COVID-19 pandemic. Inflation has increased since then. The prices of consumer goods and services in August 2021, compared to the same month last year, were increased by $5.5 \%$. Compared to the previous month, the prices of goods and services increased by $0.5 \%$ [66].

It is worth emphasizing that employment in the RE sector is growing year by year, which is important for the Polish economy. Today, almost 90,000 people are employed in the photovoltaics sector alone [67]. It is estimated that 150,000 people in Poland are employed within the RE sector. Regarding RE installations, although they are becoming cheaper every year, their price is still quite "prohibitive", especially for individual investors. Very few take into account that the operating costs of a heat pump are much lower than those of a coal-fired furnace (and the environmental and climate costs are even higher). Investors in 
RE in Poland and in the Pomerania Voivodeship may apply for co-financing/loans from both EU funds and national funds [55].

The system of green certificates has been in use since 1 October 2005, based on the amended Energy Law [68]. The rapid development of the technology of biomass co-firing with coal led to an oversupply of green certificates on the market and a reduction in their prices from around PLN 300/MWh in 2012 to around PLN 25/MWh in mid-2017 and PLN 213/MWh in October 2021. Such low certificate prices have a negative impact on the financial liquidity of many RE installations in Poland. Designing and introducing the auction support system was a revolutionary change in the area of supporting electricity generation from RE sources. This system ensures the competitiveness of entities participating in the auctions, which translates into the most favorable electricity prices and, consequently, has an impact on the costs of electricity offered to end users. The auction is won by the entrepreneurs who offer energy at the lowest selling price [69].

In Poland, interest rates are currently at a record low, but they have grown in the past. The Lombard rate is $1.00 \%$, the reference rate is $0.50 \%$, the rediscount rate is $0.51 \%$, and the deposit rate is $0.00 \%$ [70]. Polish RE investors are characterized by high innovation, entrepreneurship, and activity. They very often contribute their own ideas to improve the "conventional" technology, thanks to which the process of, e.g., methane fermentation has been improved. Increasingly, investors are developing two or more types of RE, e.g., biogas plants and PV panels. The accession to the EU and the opening of the borders allowed Poland to make an economic "leap". Since then, many trade agreements have been concluded, and there has been free movement of technologies and services. For several years, many Polish research centers have been conducting joint research projects with other research centers in the EU. The latest achievements of EU technology are more often implemented in Poland.

\subsection{PEST Analysis—Social Environment}

Table 3 presents the social environment of RE in the Pomerania Voivodeship in the context of its development potential.

Table 3. Social environment of RE in the Pomerania Voivodeship (author's own work).

\begin{tabular}{ccc}
\hline & Factor & Strengthening the RE Sector \\
\hline 1. & Demographic situation & 3.00 \\
2. & Level of education & 3.50 \\
3. & Knowledge about RE & 3.00 \\
4. & Social acceptance of RE & 4.00 \\
5. & Social acceptance for building a green economy & 3.00 \\
6. & Human resources and employee availability & 3.00 \\
7. & The impact of RE development on jobs & 4.00 \\
8. & EU membership & 4.50 \\
\hline
\end{tabular}

The population of Poland has been steadily declining for a decade. At the end of 2020, there were 38,265 million Poles, which is 273,000 fewer than in 2011 (it is worth mentioning that, for example, Gdynia has 244,000 inhabitants) [71]. The current data are even more concerning, as 75,869 people in Poland had died from COVID-19 by 11 October 2021 [72]. In the Pomerania Voivodeship, the population at the end of 2020 was 2347 thousand [71]. The Polish society is aging and the population is set to decline in the future-in 2020, the fertility rate was 1.38 [67]. It is assumed that if the fertility rate fluctuates in the range of 2.10-2.15, we can talk about the so-called simple replacement of generations. This means that, in the assumed situation, each woman of reproductive age gives birth to slightly more than two children on average. Such a state is desirable in order to be able to ensure an optimal size of the workforce in the future, and thus not to overburden the pension system. 
The unfavorable demographic situation in the Pomerania Voivodeship and in Poland has a very significant impact on the activity of the regional labor market. The related problems include the limited mobility of employment and the reduced ability to flexibly respond to changes in the labor market. A large group of the unemployed are people with higher education. Local authorities should support entrepreneurship by creating favorable employment conditions in micro- and small enterprises, which, inter alia, produce energy from RE sources [55].

Graduates of secondary schools (general and vocational) occupy a dominant position in the structure of the population according to the level of education; currently, the percentage of such people is $29.0 \%$. Since 1995 , the share of people with higher education in the 24-64 age group has increased from 9.7\% to 21.2\% [67]. Internet access, RE promotion (seminars, conferences, shows), and Poles traveling abroad have contributed to a gradual increase in knowledge of and support for RE. Secondary school students indicated that they learn about RE from the Internet, television and newspapers, and, to a lesser extent, from the curriculum content at school. Most of them assess their knowledge of RE as not very high. It is worth noting that teachers judge their knowledge of RE as good or very good, while information on RE is obtained mainly from the Internet and television [55]. Polish society has agreed to build a low-carbon economy, provided that it does not significantly increase the prices of energy and consumer goods. The respondents to this survey almost unanimously believed that the further development of renewable energy sources would have a positive impact on reducing the emission of pollutants into the environment [55].

Until recently, there were no fields of study related to RE offered by universities. Around 40 Polish universities have introduced to their offer fields of study/subjects related to RE sources. For example, at the Gdansk University of Technology, one can study "Green technologies and monitoring" [55].

The rapidly developing RE sector is looking for new employees, most often in rural areas, i.e., areas with a high unemployment rate. The technology of agricultural biogas plants fits perfectly into this scheme, thanks to which unemployment in Northern Poland may drop. Membership in the EU ensures the free movement of new technologies, as well as scientists and employees, in the RE sector.

\subsection{PEST Analysis-Technological Environment}

In recent years, the RE sector has been developing rapidly in Poland and around the world. Moreover, numerous studies have been conducted to increase the durability and efficiency of RE installations. These studies, as well as the increasing demand, make it possible to reduce/maintain the prices of RE installations [55].

Table 4 presents the technological environment of RE in the Pomerania Voivodeship in the context of its development potential. It needs to be highlighted that Polish power blocks are obsolete. Due to their poor technical condition, shutdowns are anticipated in the future. On 1 January 2018, the "Adamów" power plant was shut down. The electricity transmission network is poorly developed. It should be emphasized also that the Pomerania Voivodeship has excellent conditions for the development of RE-so it is worth developing small, local RE installations that will transmit energy almost without grid losses [55].

In Poland, there is little cooperation between industry and science. This also applies to RE. This cooperation is necessary to develop modern and cheap RE technologies. An opportunity for the development of this sector is the creation of numerous cluster initiatives, based on the endogenous potential of a given region. The efficiency of RE installations is equal to and sometimes exceeds that of conventional energy installations. Hydroenergy power plants obtain energy with an efficiency of up to $90 \%$, while agricultural biogas plants, cogenerating electricity and heat, achieve efficiency of up to $85 \%$ [55]. 
Table 4. The technological environment of RE in the Pomerania Voivodeship (author's own work).

\begin{tabular}{ccc}
\hline & Factor & Strengthening the RE Sector \\
\hline 1. & Innovativeness of the economy and the RE & 4.50 \\
2. & Energy infrastructure & 2.50 \\
3. & The power grid in the Voivodeship & 2.00 \\
4. & Economy-science cooperation & 2.00 \\
5. & RE efficiency & 4.00 \\
6. & RE potential in the Voivodeship & 4.50 \\
7. & EU membership & 4.50 \\
\hline
\end{tabular}

The RE potential calculated in Section 3 in the Pomerania Voivodeship is high. The amount of electricity would cover the Voivodeship's electricity needs, and $53 \%$ of its heat needs. Membership in the EU is an opportunity for the further economic development of Poland, including the RE sector. Cooperation and knowledge exchange take place within the European Research Area. The information society is developing.

\section{Evaluation of Renewable Energy in the Pomerania Voivodeship-Physical Aspects}

\subsection{Use of Biomass in the Pomerania Voivodeship}

Two biomass power plants with a total capacity of $2350 \mathrm{MW}$ are operating in the Pomerania Voivodeship [73]. The area of energy plantations in the Voivodeship currently amounts to nearly 1.7 thousand ha [74]. Four species of plants are cultivated: three woody species-willow, poplar, and birch-and one species of grass from the genus Miscanthus. The crop structure is dominated by fast-growing poplar, amounting to $68 \%$, with willow constituting $20 \%$ and Miscanthus constituting $12 \%$, while birch is grown in negligible amounts. There are 40 wood biomass boiler houses with a total capacity of nearly $105 \mathrm{MW}$ in the Pomerania Voivodeship. These are mainly wood-fired boiler houses; there are a few with pellets, and the boiler house at IP Kwidzyn operates with waste from the pulp and paper industry [75]. The number of straw-fired boiler houses in the Pomerania Voivodeship ranges from 25 to 30. Previously, boilers based on various Danish technological solutions were used; after being depleted, they were then replaced with more effective boilers fired with wood chips and pellets [75].

In the CHP plant in Lebork, waste generated in sawmills or furniture factories is the substrate used for the production of heat and electricity. The choice of biomass is not accidental. In the vicinity of Lębork, there are many farms (which can supply plant waste or switch to high-energy crops) and wood processing plants (which also produce wood waste). The plant has three chippers for biomass homogenization (Figure 4) [76]. Thanks to these activities, the old heating plant has reduced the combustion of coal, which had a negative impact on the environment and the health of the inhabitants.

According to the data of the Agricultural Market Agency, in the Pomerania Voivodeship, in Malbork, there is a plant producing biodiesel in the amount of 159 million $\mathrm{dm}^{3}$, and in Goszyn, there is a plant producing bioethanol in the amount of 32 million $\mathrm{dm}^{3}$. In turn, Gdańsk produces:

- liquid biocarbon in the amount of 286 million $\mathrm{dm}^{3}$;

- biopropane in the amount of 32 million $\mathrm{dm}^{3}$;

- biohydrogen in the amount of 1120 million $\mathrm{dm}^{3}$ [77]. 


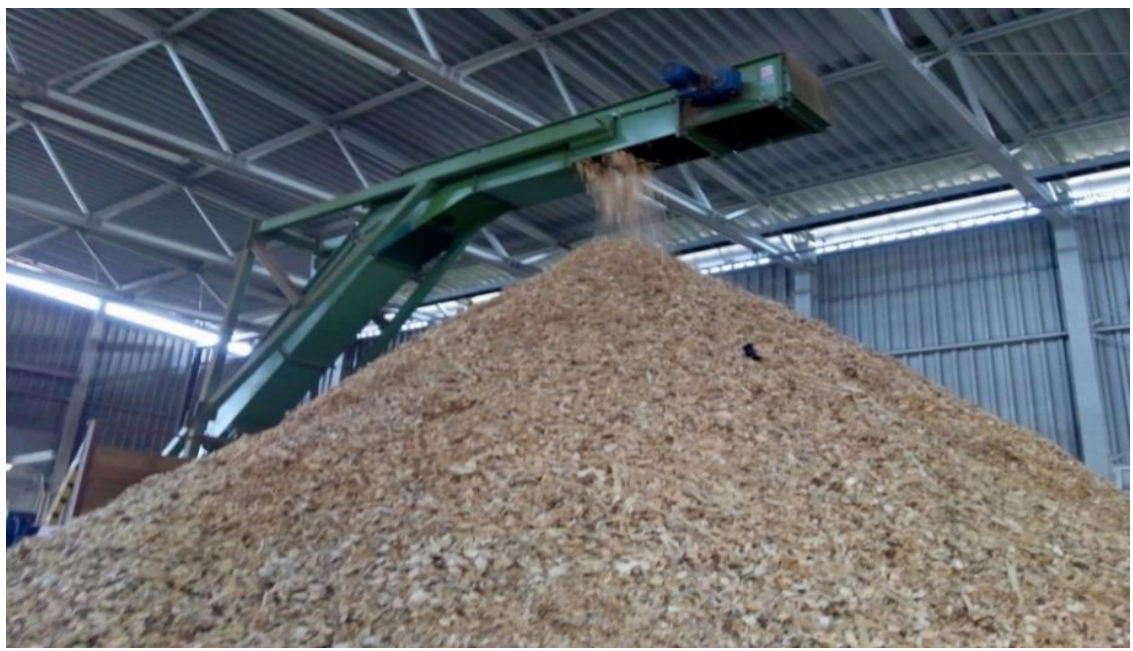

Figure 4. Chipper for biomass homogenization in Lębork (photo: B. Igliński).

There are 22 biogas plants in operation in the Voivodeship, with a total capacity of 21,843 MW (data from the Energy Regulatory Office [78]; 20 biogas plants according to the Pomerania Spatial Planning Office [75]). According to the register of agricultural biogas producers, 10 agricultural biogas plants operate in the Pomerania Voivodeship (Table 5).

Table 5. Characteristics of agricultural biogas plants in the Pomerania Voivodeship (author's own study from: [75,78]).

\begin{tabular}{|c|c|c|c|c|c|c|}
\hline \multirow{2}{*}{ City } & \multirow{2}{*}{ Substrates } & \multirow{2}{*}{$\begin{array}{l}\text { Efficiency (mln } \mathrm{m}^{3} \\
\text { Biogas/Year) }\end{array}$} & \multicolumn{2}{|c|}{ Power (MW) } & \multicolumn{2}{|c|}{$\begin{array}{l}\text { Annual Production } \\
\text { (GWh/Year) }\end{array}$} \\
\hline & & & Electricity & Heat & Electricity & Heat \\
\hline Koczała & Slurry, maize silage, straw & 9.200 & 2.126 & 2.206 & 18.000 & 19.500 \\
\hline Pawłówko & $\begin{array}{l}\text { Slurry, maize slaughterhouse } \\
\text { waste, glycerin }\end{array}$ & 3.810 & 0.946 & 0.420 & 3.000 & 3.900 \\
\hline Płaszczyca & $\begin{array}{l}\text { Slurry, maize silage, waste plant } \\
\text { mass, waste from processing } \\
\text { plant products }\end{array}$ & 2.900 & 0.625 & 0.600 & 5.300 & 5.900 \\
\hline Uniechówek & Slurry, maize silage & 4.500 & 1.063 & 1.081 & 8.380 & 8.696 \\
\hline Darżyno & $\begin{array}{l}\text { Potato waste, maize silage, } \\
\text { miscellaneous waste, slurry }\end{array}$ & 10.000 & 2.400 & 2.400 & 18.500 & 12.000 \\
\hline Lębork & Potato peelings, sewage sludge & 3.500 & 1.200 & 1.251 & 9.328 & no data \\
\hline Tragamin & $\begin{array}{l}\text { Corn silage, grass silage, } \\
\text { manure, haylage, bio-waste }\end{array}$ & 3.500 & 0.800 & 5.540 & 4.860 & no data \\
\hline Jaromierz & $\begin{array}{l}\text { Agricultural substrates, potato } \\
\text { pulp, bio-waste }\end{array}$ & 5.000 & 0.999 & 8.360 & 8.670 & no data \\
\hline Płaszczyna & $\begin{array}{l}\text { Distillation broth, corn silage, } \\
\text { grain chaff }\end{array}$ & 11.000 & 2.000 & no data & no data & no data \\
\hline Niedamowo & $\begin{array}{l}\text { Pig slurry, vegetable and } \\
\text { food waste }\end{array}$ & 1.222 & $\begin{array}{c}0.330 \\
\text { (possible } \\
\text { extension) }\end{array}$ & 0.365 & no data & no data \\
\hline
\end{tabular}




\subsection{Biomass Potential in the Pomerania Voivodeship}

\subsubsection{Amount of Energy from Wood Harvested from Forests and Wood Industry}

The technical potential of waste solid biomass and biogas from wastes in the Pomerania Voivodeship was calculated. The main source of energy is waste. In order to calculate the available energy, the following assumptions were made:

- $15 \%$ of wood harvested in the forest is "waste wood" [55];

- the calorific value of biomass from forests is $7 \mathrm{GJ} / \mathrm{m}^{3}$ (in the Voivodeship, pine is the dominant species) [79];

- the efficiency of obtaining energy is $80 \%$ (electricity from solid biomass will be obtained with an efficiency of $30 \%$, and heat with an efficiency of $50 \%$ ).

Formula (1) shows the annual amount of energy that can be obtained from wood harvested directly, i.e., logging in forests:

$$
\mathrm{E}_{\mathrm{ww}}=0.8 \cdot 0.15 \cdot \mathrm{I}_{\mathrm{w}} \cdot \mathrm{W}_{\mathrm{w}},
$$

where: $E_{w w}$-energy from wood generated in the process of logging (PJ/year), $I_{w}$-amount of wood harvested annually in forests ( 3.23 million $\mathrm{m}^{3} /$ year), $\mathrm{W}_{\mathrm{w}}$-calorific value of biomass $\left(7 \mathrm{GJ} / \mathrm{m}^{3}\right)$.

The amount of energy that can be produced from waste wood from forests in the Pomerania Voivodeship is $2.71 \mathrm{PJ} /$ year $(283 \mathrm{GWh}$ /year of electricity and $1.69 \mathrm{PJ} /$ year of heat). In order to estimate the annual energy possible from waste wood from the wood industry, the same assumptions were made, but it was assumed that industrial and post-use waste wood constitutes $25 \%$ of that harvested [53].

Formula (2) shows the amount of energy that can be obtained from wood in the woodworking industry:

$$
\mathrm{E}_{\mathrm{wi}}=0.8 \cdot 0.25 \cdot \mathrm{I}_{\mathrm{W}} \cdot \mathrm{W}_{\mathrm{w}},
$$

where: $E_{w i}$ - energy from wood generated in the wood industry (PJ/year), $\mathrm{I}_{\mathrm{w}}$-amount of wood harvested annually in forests $\left(3.75\right.$ million $\mathrm{m}^{3} /$ year $), \mathrm{W}_{\mathrm{w}}$-calorific value of biomass $\left(7 \mathrm{GJ} / \mathrm{m}^{3}\right)$.

The amount of energy that can be produced from waste wood from the wood industry in the Pomerania Voivodeship is $4.52 \mathrm{PJ} /$ year $(472 \mathrm{GWh} /$ year of electricity and $2.92 \mathrm{PJ} /$ year of heat).

A total of $40 \%$ of biomass from forests can be allocated to energy purposes (formula (3)):

$$
\mathrm{E}_{\mathrm{W}}=0.8 \cdot 0.4 \cdot \mathrm{I}_{\mathrm{W}} \cdot \mathrm{W}_{\mathrm{w}},
$$

where: $E_{\mathrm{w}}$ - energy from wood generated during logging and in the wood industry (PJ/year), $\mathrm{I}_{\mathrm{W}}$-amount of biomass harvested annually in the Voivodeship's forests ( 3.75 million $\mathrm{m}^{3}$ /year), $\mathrm{W}_{\mathrm{w}}$-calorific value of biomass $\left(7 \mathrm{GJ} / \mathrm{m}^{3}\right)$.

The obtained amount of energy that can be produced every year from waste wood in the Pomerania Voivodeship is 7.23 PJ/year (755 GWh/year of electricity and $4.51 \mathrm{PJ} /$ year of heat).

\subsubsection{The Amount of Energy from Waste Biomass from Orchards}

Orchard wood waste comes from both maintenance (e.g., cutting branches) and cleaning. The amount of wood produced annually during maintenance works varies depending on the age and species of trees—on average, it amounts to $7 \mathrm{Mg} /$ (ha.year) [80]. As a result of the grubbing up of orchards, it is possible to obtain approx. $60 \mathrm{Mg} / \mathrm{ha}$ in the case of modern, low-growing plantations (15 years) and $80 \mathrm{Mg} /$ ha of biomass in the case of older plantations (30 years) [80]; annually, this amounts to approximately $3.5 \mathrm{Mg} /$ (ha.year). In order to calculate the available energy, the following assumptions were made:

- $\quad 30 \%$ of wood harvested in orchards can be used for energy purposes [55];

- grubbing up produces $3.5 \mathrm{Mg}$ / (ha.year) of wood [80]; 
- $7 \mathrm{Mg} /$ (ha.year) of wood is produced as a result of maintenance work [80];

- the calorific value of wood of fruit trees is, on average, $11.5 \mathrm{GJ} / \mathrm{Mg}[55,80]$;

- the efficiency of obtaining energy is $80 \%$ (electricity from solid biomass will be obtained with an efficiency of $30 \%$, and heat with an efficiency of $50 \%$ ).

Formula (4) shows the amount of energy that can be obtained from waste orchard wood:

$$
\mathrm{E}_{\mathrm{o}}=0.8 \cdot 0.3 \cdot\left(\mathrm{K}_{\mathrm{g}}+\mathrm{K}_{\mathrm{c}}\right) \cdot \mathrm{P}_{\mathrm{o}} \cdot \mathrm{W}_{\mathrm{o}},
$$

where: $\mathrm{E}_{\mathrm{O}}$ - energy from orchard wood waste (PJ/year), $\mathrm{K}_{\mathrm{g}}$-amount of wood harvested annually as a result of grubbing up one hectare of orchard (3.5 Mg/(ha-year)), $\mathrm{K}_{\mathrm{c}}$ - the amount of wood harvested annually as a result of cultivation works per hectare of the orchard (7 Mg/(ha.year), $\mathrm{P}_{\mathrm{o}}$ - orchard area (2.0 thousand ha), $\mathrm{W}_{\mathrm{o}}$-calorific value of biomass from orchards $(11.5 \mathrm{GJ} / \mathrm{Mg})$.

The obtained amount of energy that can be produced every year from waste wood from orchards in the Pomerania Voivodeship is $0.058 \mathrm{PJ} /$ year $(6 \mathrm{GWh}$ /year of electricity and $0.04 \mathrm{PJ} /$ year of heat).

\subsubsection{The Amount of Energy from Surplus Straw}

In recent years, the agriculture of the Voivodeship has been dominated by the cultivation of cereals: rye, wheat, barley, oats, triticale, and cereal mixtures. According to the data of the Central Statistical Office, the annual weight of cereal grain harvested in the Pomerania Voivodeship is 874 thousand $\mathrm{Mg}$ /year of wheat, 181 thousand $\mathrm{Mg}$ /year of rye, 126 thousand $\mathrm{Mg}$ /year of barley, 66 thousand $\mathrm{Mg}$ /year of oats, and 222 thousand $\mathrm{Mg}$ /year of triticale $[81,82]$.

In order to calculate the available energy, the following assumptions were made:

- the grain/straw ratio is, respectively, 0.8 for wheat, 1.4 for rye, 0.9 for barley, 1.05 for oats, and 0.95 for triticale [4];

- $30 \%$ of produced straw is surplus that can be used for energy purposes [55];

- the calorific value of straw (with a moisture content of approximately $20 \%$ ) is, on average, $15 \mathrm{GJ} / \mathrm{Mg}[83,84]$;

- the efficiency of obtaining energy is $80 \%$ (electricity from solid biomass will be obtained with an efficiency of $30 \%$, and heat with an efficiency of $50 \%$ ).

Formula (5) shows the amount of energy that can be obtained from straw:

$$
\mathrm{E}_{\mathrm{s}}=0.8 \cdot 0.3 \cdot\left(\mathrm{Z}_{\mathrm{w}} / \mathrm{w}_{\mathrm{w}}+\mathrm{Z}_{\mathrm{r}} / \mathrm{w}_{\mathrm{r}}+\mathrm{Z}_{\mathrm{b}} / \mathrm{w}_{\mathrm{b}}+\mathrm{Z}_{\mathrm{o}} / \mathrm{w}_{\mathrm{o}}+\mathrm{Z}_{\mathrm{t}} / \mathrm{w}_{\mathrm{t}}\right) \cdot \mathrm{W}_{\mathrm{s}},
$$

where: $E_{\mathrm{s}}$ - energy from straw (PJ/year), $\mathrm{W}_{\mathrm{s}}$-the calorific value of straw $(15 \mathrm{GJ} / \mathrm{Mg})[4]$, $\mathrm{Z}_{\mathrm{w}}, \mathrm{Z}_{\mathrm{r}}, \mathrm{Z}_{\mathrm{b}}, \mathrm{Z}_{\mathrm{o}}, \mathrm{Z}_{\mathrm{t}}$-annual crops of cereal grains (wheat, rye, barley, oats, triticale) (million $\mathrm{Mg} /$ year), $\mathrm{w}_{\mathrm{w}}, \mathrm{w}_{\mathrm{r}}, \mathrm{w}_{\mathrm{b}}, \mathrm{w}_{\mathrm{o}}, \mathrm{w}_{\mathrm{t}}$ - grain/straw ratio, respectively, 0.8, 1.4, 0.9, 1.05, 0.95 [53].

The obtained amount of energy that can be produced every year from surplus straw in the Pomerania Voivodeship is $5.97 \mathrm{PJ} /$ year $(622 \mathrm{GWh}$ /year of electricity and $3.73 \mathrm{PJ} /$ year of heat).

\subsubsection{The Amount of Energy from Hay from Unused Pastures and Meadows}

The Pomerania Voivodeship has a large area of pastures and meadows; according to the data of the Central Statistical Office, this amounts to 22 thousand ha and 106 thousand ha, respectively [83]. Due to the reduction in the number of livestock (mainly cattle), as well as the change in the animal nutrition system, most of the meadows and pastures are not used. In order to calculate the available energy, the following assumptions were made:

- $15 \%$ of pastures and meadows can be used to grow hay for energy purposes [55];

- annual weight of biomass harvested per hectare of pastures is $3.6 \mathrm{Mg} /$ (ha.year), and $4.9 \mathrm{Mg}$ / (ha.year) of meadows [80];

- hay's calorific value is $14 \mathrm{GJ} / \mathrm{Mg}$ [85]; 
- the efficiency of obtaining energy is $80 \%$ (electricity from solid biomass will be obtained with an efficiency of $30 \%$, and heat with an efficiency of $50 \%$ ).

Formula (6) shows the amount of energy that can be obtained from hay from unused pastures and meadows $(\mathrm{PJ} /$ year $)$ :

$$
\mathrm{E}_{\mathrm{h}}=0.8 \cdot 0.15 \cdot\left(\mathrm{z}_{\mathrm{p}} \cdot \mathrm{P}_{\mathrm{p}}+\mathrm{z}_{\mathrm{m}} \cdot \mathrm{P}_{\mathrm{m}}\right) \cdot \mathrm{W}_{\mathrm{h}}
$$

where: $E_{h}$-energy from hay from pastures and meadows (PJ/year), $z_{p}, z_{m}$-weight of hay harvested annually per hectare from pastures and meadows ( $3.6 \mathrm{Mg} /$ (ha.year) and $4.9 \mathrm{Mg}$ /(ha.year), respectively), $\mathrm{P}_{\mathrm{m}}, \mathrm{P}_{\mathrm{p}}$-area of pastures and meadows (million ha), $\mathrm{W}_{\mathrm{h}}$-hay's calorific value (14 GJ/Mg).

The obtained amount of energy that can be produced every year from hay from unused meadows and pastures in the Pomerania Voivodeship is 1.0 PJ/year (104 GWh/year of electricity and $0.63 \mathrm{PJ} /$ year of heat).

3.2.5. The Amount of Energy from the Salix Viminalis Cultivated on Wasteland, Fallow Land, and $5 \%$ of the Cultivated Area

The Pomerania Voivodeship has a large area of wasteland (post-industrial and degraded areas) and fallow areas; according to the data of the Central Statistical Office, this amounts to 41.2 thousand ha and 12.6 thousand ha, respectively [83]. This land can be used for the production of energy crops: grasses (e.g., Miscantus), cereals (straw and bioethanol), trees (e.g., Populus L.), or shrubs (e.g., Salix viminalis). In this study, it was assumed that this would be Salix viminalis; it is a native species [86]. Salix viminalis tolerates the agroclimatic conditions practically all over Poland very well [82]. It was additionally assumed that $5 \%$ of the agricultural land area, i.e., 34.9 thousand ha, would be used for the production of bioenergy.

In order to calculate the available energy, the following assumptions were made:

- $20 \%$ of wasteland, $50 \%$ of fallow land, and $5 \%$ of agricultural land can be used for growing basket willow for energy purposes [55];

- the annual yield of Salix viminalis per hectare is $8 \mathrm{Mg} /$ (ha.year), both on fallow land and wasteland, and on arable land, it is $16 \mathrm{Mg}$ / (ha.year) [80];

- the calorific value of Salix viminalis is $19 \mathrm{GJ} / \mathrm{Mg}$ [87];

- the efficiency of obtaining energy is $80 \%$ (electricity from solid biomass will be obtained with an efficiency of $30 \%$, and heat with an efficiency of $50 \%$ ).

Formula (7) shows the amount of energy that can be obtained from the Salix viminalis grown on unused fallow land and wasteland:

$$
\mathrm{E}_{\mathrm{b}}=0.8 \cdot\left[\mathrm{Q}_{\mathrm{f}} \cdot\left(0.2 \cdot \mathrm{P}_{\mathrm{w}}+0.5 \cdot \mathrm{P}_{\mathrm{f}}\right)+\mathrm{Q}_{\mathrm{a}} \cdot 0.05 \cdot \mathrm{P}_{\mathrm{a}}\right] \cdot \mathrm{W}_{\mathrm{w}},
$$

where: $\mathrm{E}_{\mathrm{b}}$ - energy from basket willow grown on wasteland, fallow land, and agricultural land (TJ/year), $\mathrm{Q}_{\mathrm{f}}$-annual yield of basket willow per hectare on fallow and barren fields $\left(8 \mathrm{Mg} /(\right.$ ha $\cdot$ year) $), \mathrm{Q}_{\mathrm{a}}$ - annual yield of Salix viminalis per hectare on arable land $\left(16 \mathrm{Mg} /\right.$ (ha.year)), $\mathrm{P}_{\mathrm{f}}, \mathrm{P}_{\mathrm{w}}, \mathrm{P}_{\mathrm{a}}$ - area of wasteland, fallow land, and arable land (thous. ha), $\mathrm{W}_{\mathrm{w}}$ - calorific value of biomass of Salix viminalis (19 GJ/Mg).

The obtained amount of energy that can be produced every year from basket willow grown on fallow land, wasteland, and agricultural land in the Pomerania Voivodeship is 10.3 PJ (1073 GWh/year of electricity and $6.44 \mathrm{PJ} /$ year of heat).

\subsubsection{Biogas Production from Waste}

The Amount of Energy from Biogas from Animal Slurry and Bird Manure

It was assumed that biogas in the Pomerania Voivodeship would be produced from liquid manure and bird droppings, as well as from municipal waste and sewage sludge. According to the data of the Central Statistical Office, the total number of cattle, pigs, and 
poultry was $219,000,772,000$, and $6,499,000$, respectively [83]. In order to calculate the available energy, the following assumptions were made:

- coefficients for converting animals into "large livestock units" (LLU) (500 kg) are 0.8 for cattle, 0.2 for pigs, and 0.004 for poultry [55];

- the average weight of animal slurry or bird droppings produced by an LLU is $44.9 \mathrm{~kg} /$ day for cattle, $43.5 \mathrm{~kg} /$ day for pigs, and $26.8 \mathrm{~kg} /$ day for poultry;

- biogas yield from slurry is $0.050 \mathrm{~m}^{3} / \mathrm{kg}$, from pig slurry is $0.055 \mathrm{~m}^{3} / \mathrm{kg}$, and from bird manure is $0.140 \mathrm{~m}^{3} / \mathrm{kg}$ [88];

- biogas from animal slurry or bird droppings contains $60 \%$ of methane, with a calorific value of $35.73 \mathrm{MJ} / \mathrm{m}^{3}$ [88];

- the technical potential of utilization biogas is $20 \%$ of the theoretical potential;

- the efficiency of obtaining energy is $80 \%$ (electricity from biogas will be obtained with an efficiency of $35 \%$, and heat with an efficiency of $45 \%$ ).

Formula (8) shows the annual amount of energy that can be obtained from biogas obtained from animal slurry or bird manure:

$$
\mathrm{E}_{\mathrm{bg}}=0.8 \cdot 0.2 \cdot 0.6 \cdot\left(0.8 \cdot \mathrm{N}_{\mathrm{c}} \cdot \mathrm{I}_{\mathrm{c}} \cdot \mathrm{U}_{\mathrm{c}}+0.2 \cdot \mathrm{N}_{\mathrm{p}} \cdot \mathrm{I}_{\mathrm{p}} \cdot \mathrm{U}_{\mathrm{p}}+0.004 \cdot \mathrm{N}_{\mathrm{po}} \cdot \mathrm{I}_{\mathrm{po}} \cdot \mathrm{U}_{\mathrm{po}}\right) \cdot \mathrm{W}_{\mathrm{m}},
$$

where: $\mathrm{E}_{\mathrm{bg}}$ - energy from biogas obtained from animal slurry or bird manure (TJ/year), $\mathrm{N}_{\mathrm{c}}, \mathrm{N}_{\mathrm{p}}, \mathrm{N}_{\mathrm{po}}$-number of cattle, pigs, poultry (million heads), $\mathrm{I}_{\mathrm{c}}, \mathrm{I}_{\mathrm{p}}, \mathrm{I}_{\mathrm{po}}$ - annual weight of animal slurry or bird droppings from a large unit count of cattle $(16.4 \mathrm{Mg} /$ year), pigs (15.9 Mg/year), poultry ( $9.8 \mathrm{Mg} /$ year), $\mathrm{U}_{\mathrm{c}}, \mathrm{U}_{\mathrm{p}}, \mathrm{U}_{\mathrm{po}}$-biogas yield from cattle slurry $\left(50 \mathrm{~m}^{3} / \mathrm{Mg}\right)$, from pig slurry $\left(55 \mathrm{~m}^{3} / \mathrm{Mg}\right)$, from bird manure $\left(140 \mathrm{~m}^{3} / \mathrm{Mg}\right)[4], \mathrm{W}_{\mathrm{m}}$ methane's calorific value $\left(35.73 \mathrm{MJ} / \mathrm{m}^{3}\right)$.

The obtained amount of energy that can be produced every year from the utilization of biogas from animal slurry or bird manure in the Pomerania Voivodeship is 1.08 PJ (112 GWh/year of electricity and $0.68 \mathrm{PJ} /$ year of heat).

The Amount of Energy from "Landfill” Biogas

The Pomerania region generated an annual mass of municipal waste amounting to 869 thousand $\mathrm{Mg}$ /year (data of the Central Statistical Office, Households and Public Utility Facilities [84]). Unfortunately, only approximately $20 \%$ of the theoretical potential is represented by biogas from municipal waste.

The potential energy calculation was based on the following assumptions, assuming that the biogas yield from municipal waste is $100 \mathrm{~m}^{3} / \mathrm{Mg}$ [55]:

- biogas from municipal waste contains $55 \%$ methane, with a calorific value of $35.73 \mathrm{MJ} / \mathrm{m}^{3}$ [88];

- the technical potential of the utilization of biogas accounts for $20 \%$ of the theoretical potential;

- the efficiency of obtaining energy is $80 \%$ (electricity from biogas will be obtained with an efficiency of $35 \%$, and heat with an efficiency of $45 \%$ ).

Formula (9) shows the amount of energy that can be obtained from biogas obtained from the biodegradable fraction of municipal waste:

$$
\mathrm{E}_{\mathrm{bo}}=0.8 \cdot 0.2 \cdot 0.55 \cdot \mathrm{N}_{\mathrm{b}} \cdot \mathrm{U}_{\mathrm{b}} \cdot \mathrm{W}_{\mathrm{m}}
$$

where: $E_{\mathrm{bo}}$ - energy from biogas from the biodegradable fraction of municipal waste (TJ/year), $\mathrm{N}_{\mathrm{b}}$-mass of biodegradable fraction of municipal waste (million $\mathrm{Mg}$ /year), $\mathrm{U}_{\mathrm{b}}$ - biogas yield from the biodegradable fraction of municipal waste $\left(100 \mathrm{~m}^{3} / \mathrm{Mg}\right)$ [53], $\mathrm{W}_{\mathrm{m}}$-methane calorific value $\left(35.73 \mathrm{MJ} / \mathrm{m}^{3}\right)$.

The amount of energy that can be obtained annually from biogas from the biodegradable fraction of municipal waste in the Pomerania Voivodeship is $0.273 \mathrm{PJ} /$ year $(28 \mathrm{GWh}$ /year of electricity and $0.154 \mathrm{PJ} /$ year of heat). 
The Amount of Energy from Biogas in Wastewater Treatment Plants

In the Pomerania Voivodeship, 44.8 million $\mathrm{m}^{3}$ of municipal wastewater is treated annually [89]. It was assumed that $50 \%$ of the sewage flowing into the treatment plant would obtain sludge (constituting $1 \%$ of the sewage) and that $1 \mathrm{~m}^{3}$ of sludge can be used to obtain $15 \mathrm{~m}^{3}$ of biogas [88].

In order to calculate the available energy, the following assumptions were made:

- $50 \%$ of municipal wastewater will be used to obtain biogas [55];

- the volume of sewage sludge is $1 \%$ of the incoming municipal sewage [88];

- biogas yield from sewage sludge is $15 \mathrm{~m}^{3} / \mathrm{m}^{3}=15$ [88];

- biogas from sewage sludge contains $60 \%$ methane, with a calorific value of $35.73 \mathrm{MJ} / \mathrm{m}^{3}$ [90];

- the efficiency of obtaining energy is $80 \%$ (electricity from biogas will be obtained with an efficiency of $35 \%$, and heat with an efficiency of $45 \%$ ).

Formula (10) shows the amount of energy that can be obtained from biogas obtained from sewage sludge:

$$
\mathrm{E}_{\mathrm{bs}}=0.8 \cdot 0.5 \cdot 0.01 \cdot 0.6 \cdot \mathrm{V}_{\mathrm{bs}} \cdot \mathrm{U}_{\mathrm{bs}} \cdot \mathrm{W}_{\mathrm{m}}
$$

where: $\mathrm{E}_{\mathrm{bs}}$ - energy from utilization biogas from sewage sludge (TJ/year), $\mathrm{V}_{\mathrm{bs}}$ - annual volume of municipal wastewater flowing into the treatment plant (million $\mathrm{m}^{3} /$ year), $\mathrm{U}_{\mathrm{bs}}$ - biogas yield from sewage sludge $\left(15 \mathrm{~m}^{3} / \mathrm{m}^{3}\right)$ [88], $\mathrm{W}_{\mathrm{m}}$-methane calorific value (35.73 MJ/m³).

In total, 3.4 million $\mathrm{m}^{3}$ of biogas can be obtained in the Pomerania Voivodeship, i.e., approximately $0.13 \mathrm{PJ} /$ year of energy ( $13 \mathrm{GWh} /$ year of electricity and $0.07 \mathrm{PJ} /$ year of heat).

\subsection{Wind Energy in the Pomerania Voivodeship}

As shown in the wind speed map at the height of $140 \mathrm{~m}$ (Figure 5), it can be stated that the Pomerania Voivodeship provides very favorable conditions for wind energy generation. The Voivodeship is especially well-suited for the development of wind energy - not only on land but also offshore. Offshore wind energy may become a flywheel for companies from the region, including shipyards, which already today produce components for the offshore industry [91].

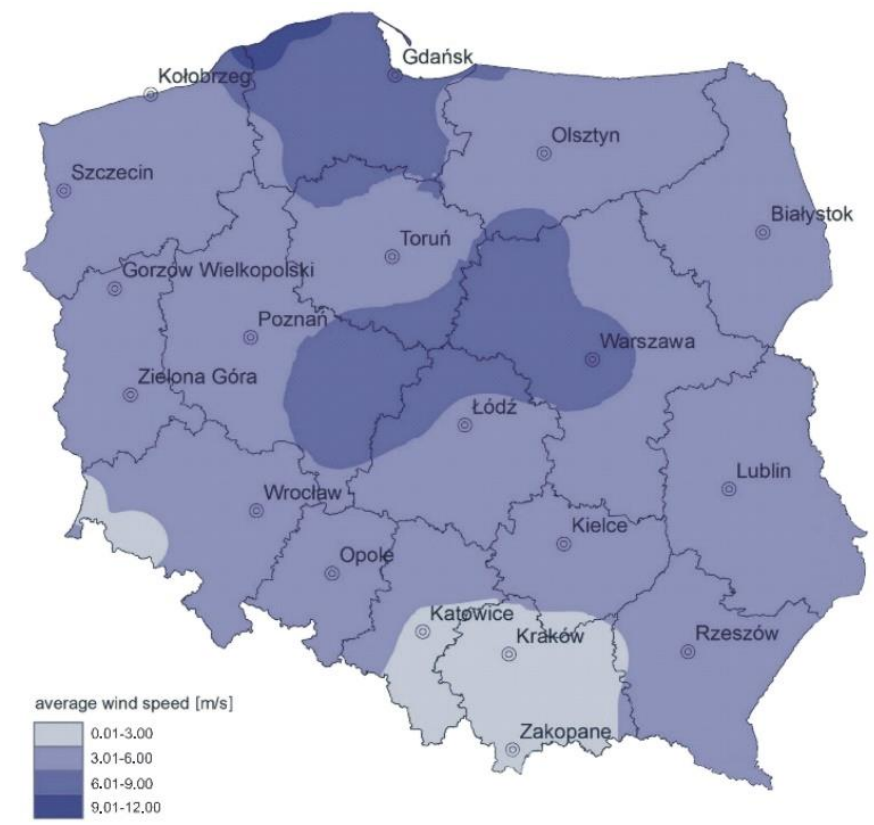

Figure 5. Wind speed analysis. Height of $140 \mathrm{~m}$ (own study from [92]). 
The total capacity of wind farms in the Pomerania Voivodeship is $786 \mathrm{MW}$. In the draft program for the development of offshore wind energy and maritime industry, taking into account the available area of the Polish exclusive economic zone (2000 $\mathrm{km}^{2}$ by 2030), wind conditions, productivity, and installed power density $\left(6 \mathrm{MW} / \mathrm{km}^{2}\right)$, the theoretical potential was estimated at the level of $12 \mathrm{GW}$, with a generation potential of approximately 48-56 TWh. On the other hand, the technical potential of offshore energy was estimated to reach 7.4 GW by 2030 (Figure 6) [93].

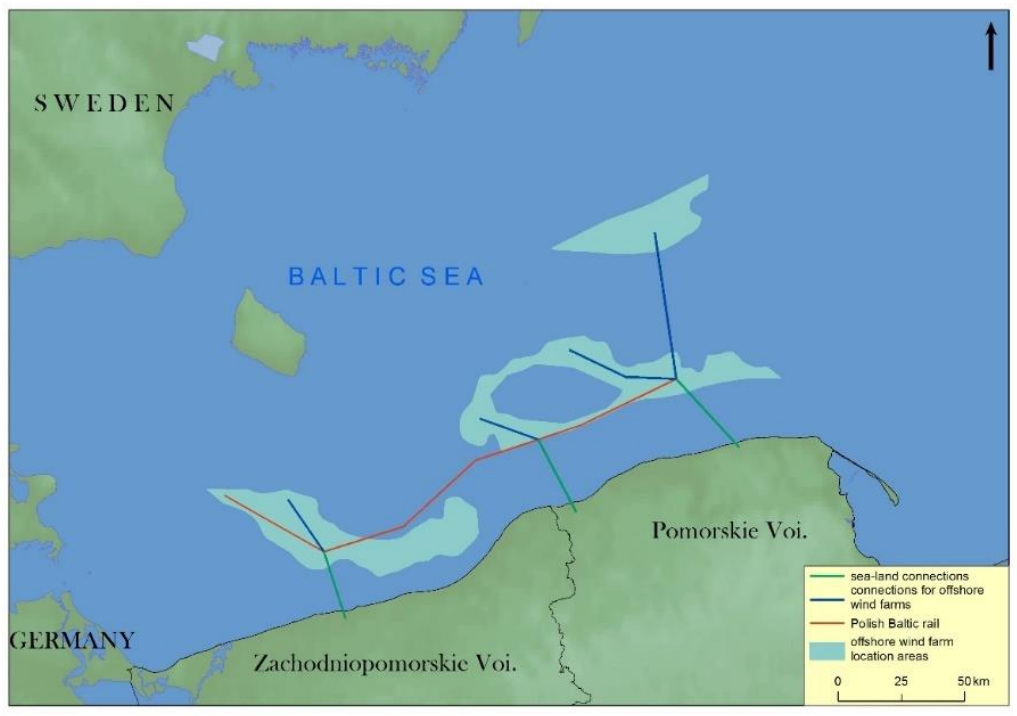

Figure 6. Potential locations of offshore wind farms in Poland (own study from [93]).

The Polska Grupa Energetyczna (Polish Energy Group) and Danish Ørsted have signed an investment agreement aimed at the development, construction, and operation of two offshore aeroenergy projects in the Baltic Sea, with a total capacity of approximately 2.5 GW. These are the Baltica-3 Wind Power Plant, with a capacity of over $1 \mathrm{GW}$, and the Baltica-2 Wind Power Plant, with a capacity of approximately $1.5 \mathrm{GW}$. Baltica-2 and Baltica-3 are eligible for participation in 2021 in the first phase of the operation of the offshore wind support scheme in Poland for wind farms with a total capacity of 5.9 GW. This system is a result of the new act to promote electricity generation in offshore wind farms, which was announced on 3 February 2021 in the Journal of Laws [94].

The technical potential of wind energy in the Pomerania Voivodeship was calculated. For this purpose, it was assumed that $140 \mathrm{~m}$ turbines will be erected, which means that the height of a turbine with a blade will be $215 \mathrm{~m} \mathrm{(h).} \mathrm{The} \mathrm{"Distance} \mathrm{Act"} \mathrm{[56]} \mathrm{requires}$ that the distance from residential buildings, areas of natural protection, and promotional forest complexes should be $10 \mathrm{~h}$, i.e., $2150 \mathrm{~m}$. The calculations performed indicate that the total area of the available areas is $60 \mathrm{~km}^{2}$, i.e., only $0.3 \%$ of the area of the Pomerania Voivodeship (Figure 7). The amount of energy generated from aeroenergy in the Pomerania Voivodeship is $5.68 \mathrm{PJ}$, or 1.56 TWh. It is possible to make these assumptions early on, and this is the result of the "Distance Act" [56]. Its relaxation llows this system to produce many times more energy. 


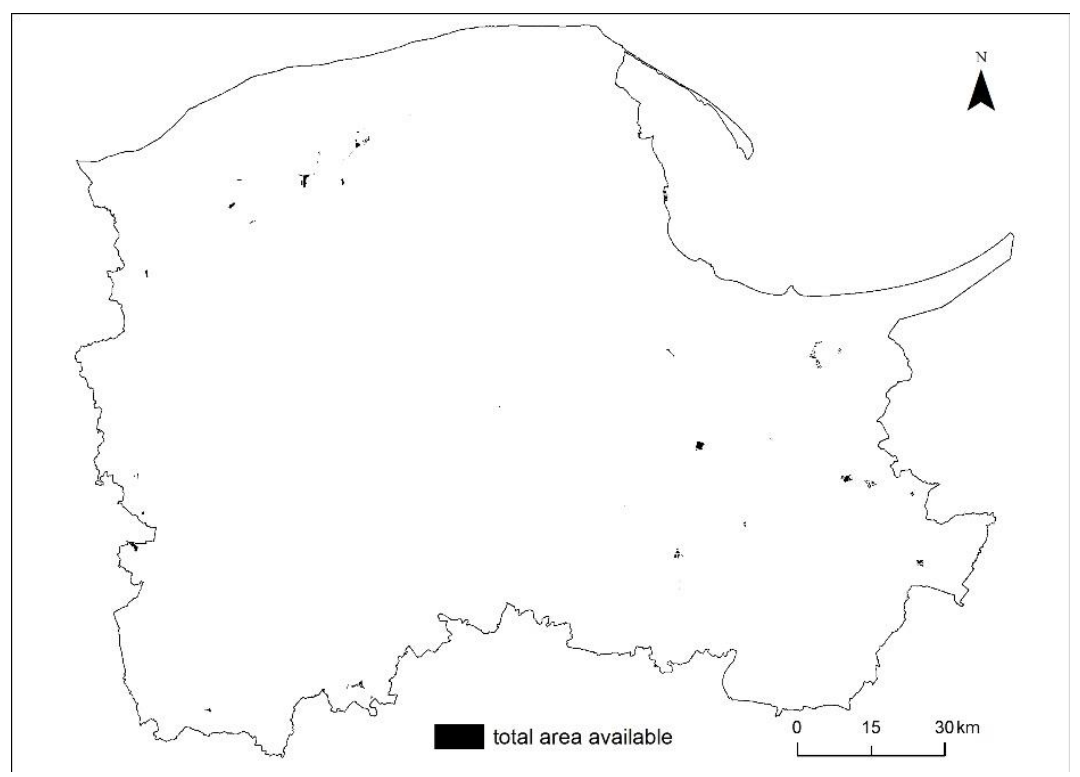

Figure 7. Area available for the development of aeroenergy in the Pomerania Voivodeship (own study).

\subsection{The Potential of Hydropower in the Pomerania Voivodeship}

The Pomerania region lies on the outskirts of two rivers-the Odra and the Vistula. As part of the Vistula River, which covers $86 \%$ of the province, it is possible to distinguish two hydrographic systems-Kashubian and Delta. According to Energy Regulatory Office data [78], there are 108 hydropower plants in the Pomerania Voivodeship, with a capacity of $34 \mathrm{MW}$. Considering that $\mathrm{g}=9.81 \mathrm{~m} / \mathrm{s}^{2}$ and $\rho=1000 \mathrm{~kg} / \mathrm{m}^{3}$ and then $=0.85$, we obtain:

$$
\mathrm{P}=9.81 \cdot \theta \cdot \mathrm{H} \cdot \eta
$$

where:

-the capacity of a water turbine, or the volume of a stream of water flowing through the turbine within $1 \mathrm{~s}\left(\mathrm{~m}^{3} / \mathrm{s}\right)$;

$\mathrm{H}-$ head (m);

-the efficiency of the water turbine, the gear, and the generator (Korolewski and Ligocki 2004).

Assuming efficiency at the level of $85 \%$, we obtain the following model:

$$
\mathrm{P}=8.34 \cdot \mathrm{H} \cdot \theta
$$

Assuming that the electronics will be able to operate for $6000 \mathrm{~h} /$ year at full power, i.e., $21,600,000 \mathrm{~s} /$ year, the annual amount of electricity from a given hydroelectric power plant $\mathrm{E}_{\mathrm{el}}$, for the output year (after conversion Wh to MWh), can be calculated as follows [4]:

$$
\mathrm{E}_{\mathrm{k}}=21.6 \cdot \mathrm{P}
$$

In the Pomerania Voivodeship, there are a number of facilities that can be used to produce electricity. These provide equally inexhaustible levels of water, serving in the past to fulfil energy targets, as well as for the identification of objects present in water during land reclamation. Based on the Equation (13) and data of the National Water Management Board on the levels of leveling and flooding (clearer, overflows) of water on the general furnaces, the theoretical power of electric and electric water, which can be calculated, is calculated.

In the Pomerania Voivodeship, the number of existing dams is:

- 154 dams on which a small hydropower plant (SHP) with a capacity of less than $5 \mathrm{~kW}$ can be placed; 
- 95 dams on which a 5-10 kW SHP can be placed;

- 88 dams on which a 10-20 kW SHP can be placed;

- 67 dams on which a 20-50 kW SHP can be placed;

- $\quad 35$ dams on which a 50-100 kW SHP can be placed;

- 48 dams on which one can place an SHP with a capacity of 100-500 kW;

- 4 dams on which an SHP with a capacity of over $500 \mathrm{~kW}$ can be placed (Figure 8).

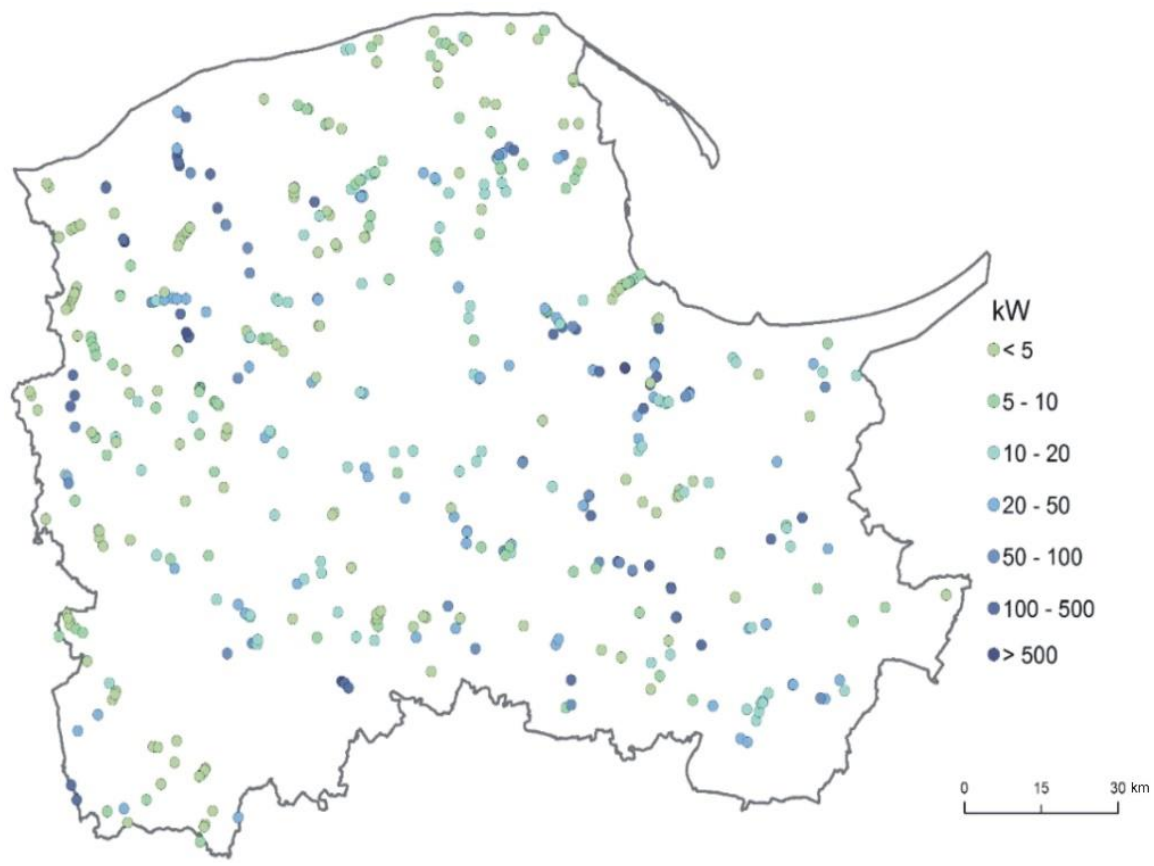

Figure 8. The location of the dams and the power of small hydroenergy plants that can be built in the Pomerania Voivodeship (own study from [95]).

The total theoretical electric power of all dams is $40.1 \mathrm{MW}$. This potential can, of course, be increased by building new water dams.

\subsection{Solar Energy in the Pomerania Voivodeship}

\subsubsection{PV Potential on Roofs}

The Pomerania Voivodeship has average/good conditions for the development of solar energy. At the end of 2020, there were already 89 photovoltaic (PV) farms in the region, with a total capacity of 59.2 MW [78]. There are also thousands of prosumer installations and thousands of solar collectors.

It was assumed that $10 \%$ of roofs in the Pomerania Voivodeship will be covered by PV. The value of electricity that can be obtained from the PV panels can be obtained from the following formula [55]:

$$
\mathrm{E}_{\mathrm{r}}=0.1 \cdot 0.15 \cdot \mathrm{P}_{\mathrm{d}} \cdot \mathrm{U} \cdot \mathrm{N},
$$

where: $\mathrm{E}_{\mathrm{r}}$ - electricity that can be obtained annually from $\mathrm{PV}$ on roofs $(\mathrm{J} /$ year $), \mathrm{P}_{\mathrm{d}}$-roof area $\left(62.3 \mathrm{~km}^{2}\right)\left(\mathrm{m}^{2}\right), \mathrm{U}$-insolation (h/year), converted to (s/year), $\mathrm{N}$-insolation $(\mathrm{W} / \mathrm{m} 2)$.

The received annual amount of energy is $0.231 \mathrm{TWh}(833 \mathrm{TJ})$.

\subsubsection{PV in Wasteland}

The Pomerania Voivodeship has a large area of wasteland, with a total area of 41.2 thousand ha [80]. It was assumed that $20 \%$ of the wasteland in the Voivodeship will be subjected to reclamation in the "energy direction", where PV farms will be erected. The calculations took into account the insolation and solar irradiance of individual areas of Poland (data from the Institute of Meteorology and Water Management), and then the 
amount of electricity that can be obtained from PV panels with an efficiency of $15 \%$ was calculated, using the following formula [55]:

$$
\mathrm{E}_{\mathrm{W}}=0.20 \cdot 0.15 \cdot \mathrm{Pn} \cdot \mathrm{I} \cdot \mathrm{S},
$$

where: $\mathrm{E}_{\mathrm{w}}$-electricity that can be obtained annually from PV in wasteland (J/year), $\mathrm{P}_{\mathrm{w}}$ wasteland area $\left(\mathrm{m}^{2}\right), \mathrm{I}$-insolation (h/year), converted to (s/year), $\mathrm{N}$-solar irradiance $\left(\mathrm{W} / \mathrm{m}^{2}\right)$.

The amount of electricity generated from PV will be 1.14 TWh $(4120 \mathrm{TJ})$.

\subsubsection{PV on Roads}

The total length of public roads with hard surfaces in the Pomerania Voivodeship is $14,547 \mathrm{~km}$ [96]. It has been assumed that it is technically possible to place $10-\mathrm{m}$-wide photovoltaic panels on $10 \%$ of the road length. We calculated how much electricity can be obtained with PV panels with an efficiency of 15\%, using the following formula:

$$
\mathrm{E}_{\mathrm{r}}=0.10 \cdot 0.15 \cdot \mathrm{D}_{\mathrm{r}} \cdot \mathrm{U} \cdot \mathrm{N}
$$

where: $\mathrm{E}_{\mathrm{r}}$ - electricity that can be obtained annually from PV (J/year), $\mathrm{D}_{\mathrm{a}}$-length of roads with hard surface $(\mathrm{m}), \mathrm{U}$-insolation (h/year), converted to (s/year), $\mathrm{N}$-insolation $\left(\mathrm{W} / \mathrm{m}^{2}\right)$.

The calculated amount of obtainable electricity is $8112 \mathrm{TJ}$, i.e., $2254 \mathrm{TWh}$. The electricity produced can be used to power traffic lights, roadside bars, restaurants, etc. The estimated total amount of energy that can be obtained from PV in the Pomerania Voivodeship is $3625 \mathrm{TWh}$. Of course, this potential can be increased by making greater use of, for example, roofs or closed landfills.

\subsection{Geothermal and Heat Pumps in the Pomerania Voivodeship}

Figure 9 shows geological wells with a depth of at least $500 \mathrm{~m}$ in the Pomerania Voivodeship. Some of them could be used in the future to build heating plants and/or geothermal thermal springs [97]. In general, the Pomerania Voivodeship does not have sufficient conditions for the development of "deep" geothermal energy. However, heat pumps can be used on a large scale in this region.

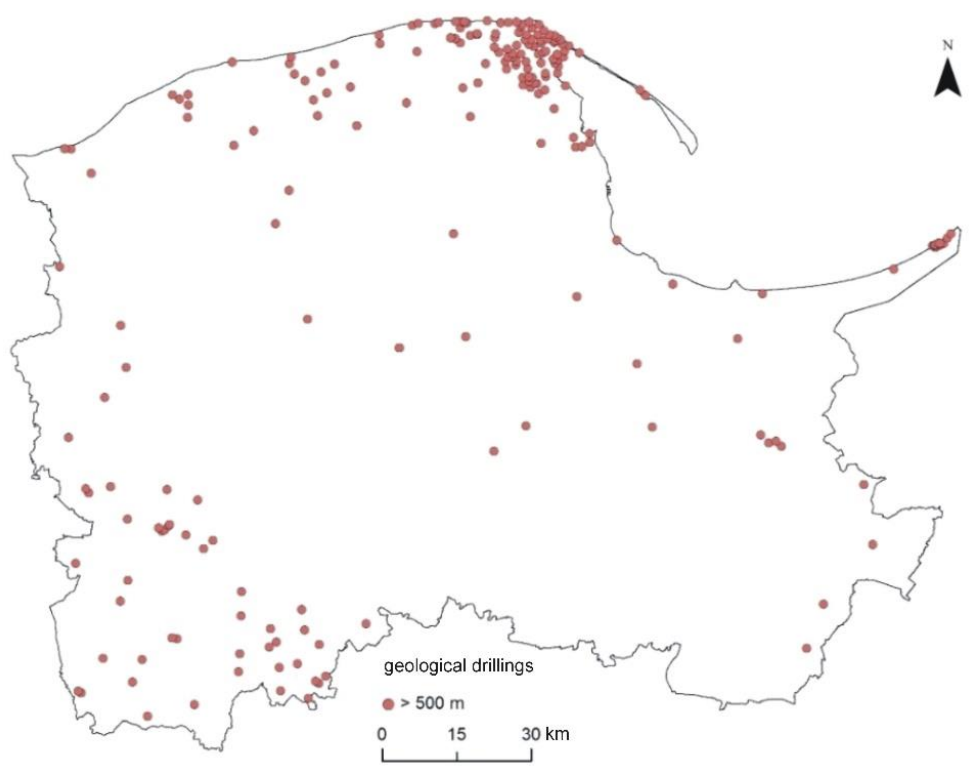

Figure 9. Geological drilling with a depth of at least $500 \mathrm{~m}$ in the Pomerania Voivodeship (own study from [97]). 
It was assumed that heat pumps will be installed in schools, kindergartens, accommodation, and cultural facilities. It was assumed that every fifth facility with a building area of $1500 \mathrm{~m}^{2}$ will be heated on average, and the heat pump's heating power will be $70 \mathrm{~W} / \mathrm{m}^{2}$. The power of the heat pump $\mathrm{P}$ is the product of the area and the unit power of $70 \mathrm{~W} / \mathrm{m}^{2}$ [55]. Assuming an operating time of $2000 \mathrm{~h}$ a year and a heat pump's coefficient of performance $(C O P)=3.8$, the annual amount of heat produced can be calculated as follows:

$$
\mathrm{E}=\mathrm{P} \cdot \mathrm{COP} \cdot \mathrm{t},
$$

where: E-heat production (MJ/year), $\mathrm{P}$ - power of heat pumps (MW), COP-coefficient of performance, $\mathrm{t}$-annual operation time of the heat pump. 1708 PJ.

The calculated amount of energy for heat pumps in schools in the Voivodeship is

In 2020, there were 1555 tourist accommodation establishments in the Pomerania Voivodeship (as a result of the COVID-19 pandemic, this figure has decreased by 103 less compared to 2019), including hotels, motels, and guest houses [92]. It was assumed that $20 \%$ of such facilities will have a heat pump, the average area of a single facility is $1000 \mathrm{~m}^{2}$, and the heat pump's heating power is also $70 \mathrm{~W} / \mathrm{m}^{2}$ [53]. Assuming the operation of heat pumps for $2000 \mathrm{~h}$ a year, on the basis of formula (16), it was calculated that the annual heat production in the Voivodeship will be 0.614 PJ.

In 2019, a total of 330 cultural facilities operated in the voivodship [98]. It was assumed that $20 \%$ of such facilities will have a heat pump, the average area of a single facility is 500 $\mathrm{m}^{2}$, and the heat pump's heating power is also $70 \mathrm{~W} / \mathrm{m}^{2}$ [53]. Assuming the operation of heat pumps for $1500 \mathrm{~h}$ a year, based on formula 17 it was calculated that the annual heat production in cultural facilities would amount to $0.052 \mathrm{PJ}$.

\section{Discussion}

The political environment of RE science and research can be classified as relatively neutral (3.29 points) in the Pomerania Voivodeship. The main opportunity for the development of RE is represented, above all, by Poland's participation in the structures of the EU and active participation in the European Research Area. The main threats to the sphere of science and research in RE include extensive and complicated laws and low effectiveness in the practical implementation of the assumptions of the innovation policy.

The economic environment can be considered relatively conducive to the development of RE (3.56 points). One opportunity for development is, first of all, membership in the $\mathrm{EU}$, which allows for financing research and investments in RE. Additionally, another opportunity is the relative stability of the economic situation in the Pomerania Voivodeship, as well as the innovativeness and activity of investors. Risks include high investment costs and fluctuating green certificate prices.

The social factor can be classified as positive to the RE sphere (3.50 points). The main opportunity is, above all, membership in the EU and the use of integration processes to educate society. Transnational partnership and investments in human capital are being developed. The main threats include the maintenance of the low reputation of science in society, the aging of society, and the demographic decline.

The technological factor can be considered neutral (3.43 points). The main opportunity for development is primarily the high efficiency of RE installations, as well as the transfer of technologies and techniques. The greatest threats are the poor condition of the power grid in Poland, little cooperation between science and the economy, and too few domestic producers of RE installations.

In summary, the PEST analysis shows that there are opportunities for the further development of RE in the Pomerania Voivodeship. Friendly legal regulations, greater financial subsidies, public education, and the development of domestic producers of RE installations may contribute to a significant reduction in GHG emissions and the greater energy independence of Poland. 
The idea of the balanced development of the Pomerania Voivodeship is based on the rational production of energy from natural resources and renewable sources. Equilibrium (eco-development) has made it possible to meet the economic, social, and environmental needs of the next generation without compromising on the ability to meet the needs of future generations. The Pomerania region already ranks third in Poland in terms of the generation of electricity from renewable sources. In quantified terms, the use of RE in the Pomerania Voivodeship appears satisfactory, although the production of "green energy" still shows room for development [99]. Bioenergy, PV, and aeroenergy are characterized by the greatest potential regarding RE in the Pomerania Voivodeship. The potential of wind energy is significant in the case of the "Distance Act" agreement. The construction and operation of offshore wind farms will be a great opportunity for the economic development of the Pomerania Voivodeship. Then, the Voivodeship will become the main exporter of energy in Poland.

The Pomerania Voivodeship can become energy-independent in the future. The potential of RE electricity is greater than needed, and it is necessary to increase the amount of biomass for heating needs, and to install more solar collectors and heat pumps, as well improving the energy efficiency. RE may become an important factor for the economic development of the Pomerania Voivodeship. Today, there is a great demand in Poland for heat pumps and solar panels. Their production and assembly should be carried out by Polish companies. The development of RE in the Voivodeship is also an opportunity for cheaper electricity and heat. Each new RE installation/power plant brings huge financial benefits for the Voivodeship. Various types of taxes are transferred to the Voivodeship's coffers. A new RE plant means new jobs, resulting in a decline in unemployment in the voivodship.

Table 6 shows the amount of energy that can be obtained from RE in the Pomerania region. The energy mix should consist of bioenergy, aeroenergy, and PV. It should be emphasized that the energy mix will allow the energy self-sufficiency of the Pomerania region. When investing in RE, one should also consider strategies to increase energy efficiency.

Table 6. Annual potential electricity and heat from renewable sources in the Pomerania Voivodeship (author's own study).

\begin{tabular}{ccc}
\hline RE Sector & Electricity (TWh/Year) & Heat (PJ/Year) \\
\hline Bioenergy & 3.03 & 16.17 \\
Aeroenergy & 1.56 & \\
Hydroenergy & 0.15 & \\
PV & 3.63 & 2.37 \\
Heat pumps & & 18.56 \\
\hline Summary & 8.37 & \\
\hline
\end{tabular}

In the Pomerania region, in 2018, 35 PJ of heat and 7.5 TWh of electricity were consumed. According to the authors' calculations, the obtainable amount of energy from RE would be 8.37 TWh, in which the total amount of heat 18.56 PJ (Table 6). The calculated amount of electricity would cover the entirely of the Voivodeship's electricity needs, and $53 \%$ of its heat requirement [100]. Heat consumption should be reduced through thermal modernization measures. After thermal modernization, a building can consume up to $60-70 \%$ less energy than before modernization. Thus, passive, zero-energy, or even plus-energy buildings are becoming increasingly popular.

\section{Summary}

The focus of this article concerned the problem of the energy transformation of the EU countries, which is understood as the transition to an economy that produces and consumes largely energy from renewable sources. It was emphasized that the strategic goal of the EU's energy policy is the transition to a "green economy". According to the EU strategy, the activities carried out by 2050 are expected to lead to the improvement of the energy 
sector towards neutrality to the climate and the environment. Transforming the economies of the EU Member States into environmentally neutral economies requires huge effort in changing and adapting many governmental/institutional policies, business strategies, and consumer behavior. It is a great challenge for the EU to set up coordinated strategies at national and local levels to reduce energy consumption and waste to zero by 2050 and become the first climate-neutral continent. Even the short-term goals (2030) proposed in the EU strategy must be based on coordination within all four aspects: institutional, economic, environmental, and physical aspects. We performed our study at the regional level in terms of RE and energy transformation in several steps.

The PEST analysis to study the macro-environment of the Pomerania Voivodeship was performed first. The authors found that the policy in the field of RE at the Voivodeship level is not very conducive to the renewable energy sector. The RE Act [55] is quite often amended and this discourages potential investors; however, the Polish energy policy until 2040 offers an opportunity for the development of RE in the Pomerania Voivodeship. Despite the unfavorable institutional and demographics in the Pomerania Voivodeship, we evaluated the economic environment of RE in the Pomerania Voivodeship in the context of its development potential quite positively (3.56 out of 5 ). The PEST analysis showed that $\mathrm{RE}$ sector has a chance for further development in the Pomerania Voivodeship.

Next, the authors evaluated the physical potential of RE in the region. On the basis of the conducted analyses, it was found that the Pomerania Voivodeship offers very favorable conditions for wind energy and solar energy but does not have these conditions for "deep" geothermal energy (however, heat pumps can be used on a large scale here). We can conclude that the Pomerania Voivodeship displays all the necessary physical conditions for the production of energy from renewable sources.

Our goal was to examine the situation of the RE sector in the Pomerania region in the context of energy transformation. The Pomerania Voivodeship has an appropriate level of RE potential and may become an energy self-sufficient region. The estimated amount of RE electricity may also cover the Voivodeship's needs. The implementation of the goal allowed for the verification of this hypothesis, which confirms that all the EU's Member States' and regional governments' efforts are reasonable and the SDGs are achievable.

In summary, we can state that the calculated amount of electricity would cover fully the Voivodeship's electricity needs, and $53 \%$ of its heat needs. The vision in both the short- (2030) and long-term (2050) acts is to reach the level of 100\% RE-based heating and cooling in Europe, which is achievable. The authors provide evidence at the level of one region (Pomeranian Voivodeship) that both EU strategies may be realistic and achievable under certain conditions. Thanks to the results obtained in one region, we know that there is significant potential to increase the RE share for the whole EU's heating and cooling sector and, at the same time, a higher refurbishment rate is also possible. Efficient and technologically smarter buildings should be the basis of Europe's decarbonization, but more effort, however, should be devoted towards renovating the current building stock. Reaching climate targets without decarbonizing them seems impossible. We conclude that, under certain conditions, and only with the EU, country-, and region-level institutional support, it will be possible to decarbonize EU building stock by 2050.

The obtained results indicate the necessity to extend the research of the energy sector in Poland to the entire territory of the country; then, SWOT analysis, PEST analysis, and analysis of the RE potential in terms of electricity and heat production can be performed. The conclusions drawn from the research would allow us to answer the questions of whether Poland is ready for the energy transformation based on the RE sources, which barriers should be overcome, what to pay attention to, and the opportunities and threats related to this process. The limitations of the research carried out in the article should also be emphasized. They are related to the differentiation of each region in Europe in terms of the analyzed conditions. The PEST analysis carried out and the GIS methods used constitute a universal tool for assessing the potential of the energy sector in the given region. However, it should be remembered that the analysis carried out must be based 
on detailed knowledge of the above-mentioned aspects of the region, cooperation with an expert panel, and the authors' extensive scientific experience in the energy sector. It should also be emphasized that it is difficult to obtain data at such a low level of aggregation as the Voivodeship.

Author Contributions: Conceptualization, B.I., K.F. and M.B.P.; methodology, B.I., K.F. and M.B.P.; software, M.S. and M.B.P.; validation, B.I., K.F., M.B.P., U.K., M.S., A.Z. and K.N.; formal analysis, B.I., M.S. and M.B.P.; investigation, B.I., K.F., M.B.P., U.K., M.S., A.Z. and K.N.; resources, B.I., K.F., M.B.P., U.K., M.S., A.Z. and K.N.; data curation, M.B.P. and B.I.; writing-original draft preparation B.I., K.F. and M.B.P.; writing-review and editing, B.I., K.F., M.B.P., U.K., M.S., A.Z. and K.N.; visualization, B.I., K.F., M.B.P. and M.S.; supervision, B.I. and M.B.P.; project administration, B.I. and M.B.P. All authors have read and agreed to the published version of the manuscript.

Funding: This research received no external funding.

Institutional Review Board Statement: Not applicable.

Informed Consent Statement: Not applicable.

Data Availability Statement: Data available on request due to restrictions. The data presented in this study are available on request from the corresponding author.

Conflicts of Interest: The authors declare no conflict of interest.

\section{References}

1. Overland, I. Energy: The missing link in globalization. Energ. Res. Soc. Sci. 2016, 14, 122-130. [CrossRef]

2. Rees, W.E. Globalization, trade and migration: Undermining sustainability. Ecol. Econ. 2006, 59, 220-225. [CrossRef]

3. Młynarski, T. Unia Europejska w procesie transformacji energetycznej. Krak. Studia Międzynarodowe 2019, 1, 31-44.

4. Igliński, B.; Skrzatek, M.; Iwański, P.; Krukowski, K. Energia Odnawialna w Województwie Warmińsko-Mazurskim; Nicolaus Copernicus University: Toruń, Poland, 2020.

5. Lin, M.-X.; Liou, H.M.; Chou, K.T. National energy transition framework toward SDG7 with legal reforms and policy bundles: The case of Taiwan and its comparison with Japan. Energies 2020, 13, 1387. [CrossRef]

6. Pietrzak, M.B.; Igliński, B.; Kujawski, W.; Iwański, P. Energy transition in Poland—assessment of the renewable energy sector. Energies 2021, 14, 2046. [CrossRef]

7. Chovancová, J.; Tej, J. Decoupling economic growth from greenhouse gas emissions: The case of the energy sector in V4 countries. Equilib. Q. J. Econ. Econ. Policy 2020, 15, 235-251. [CrossRef]

8. Gajdos, A.; Arendt, L.; Balcerzak, A.P.; Pietrzak, M.B. Future trends of labour market polarisation in Poland. The Perspective of 2025. Trans. Bus. Economy 2020, 19, 114-135.

9. Bhattacharya, M.; Churchill, S.A.; Paramati, S.R. The dynamic impact of renewable energy and institutions on economic output and $\mathrm{CO}_{2}$ emissions across regions. Renew. Energ. 2017, 111, 157-167. [CrossRef]

10. Saidi, H.; El Montasser, G.; Ajmi, A.N. The role of institutions in the renewable energy-Ggrowth Nnexus in the MENA region: A panel cointegration approach. Environ. Model Assess 2020, 25, 259-276. [CrossRef]

11. Schoenefeld, J.J.; Knodt, M. Softening the surface but hardening the core? Governing renewable energy in the EU. West Europ. Pol. 2021, 44, 49-71. [CrossRef]

12. Gawlik, L. The Polish power industry in energy transformation process. Miner. Econ. 2018, 31, 229-237. [CrossRef]

13. Zielenkiewicz, M. Institutional environment in the context of development of sustainable society in the European Union countries. Equilibrium. Quart. J. Econ. Econ. Pol. 2014, 9, 21-37.

14. Grosse, T.G. Low carbon economy policy in Poland: An example of the impact of europeanisation. Equilibrium. Q. J. Econ. Econ. Policy 2011, 6, 9-39. [CrossRef]

15. Cheba, K.; Szopik-Depczyńska, K. Multidimensional comparative analysis of the competitive capacity of the European Union countries and geographical regions. Oecon. Copernic. 2017, 8, 487-504. [CrossRef]

16. Szopik-Depczyńska, K.; Kędzierska-Szczepaniak, A.; Szczepaniak, K.; Cheba, K.; Gajda, W.; Ioppolo, G. Innovation in sustainable development: An investigation of the EU context using 2030 agenda indicators. Land Use Pol. 2018, 79, 251-262. [CrossRef]

17. Szopik-Depczyńska, K.; Cheba, K.; Bąk, I.; Stajniak, M.; Simboli, A.; Ioppolo, G. The study of relationship in a hierarchical structure of EU sustainable development indicators. Ecol. Indic. 2018, 90, 120-131. [CrossRef]

18. Kijek, T.; Matras-Bolibok, A. The relationship between TFP and innovation performance: Evidence from EU regions. Equilibrium. Q. J. Econ. Econ. Policy 2019, 14, 695-709. [CrossRef]

19. Kijek, A.; Matras-Bolibok, A. Technological convergence across European regions. Equilibrium. Q. J. Econ. Econ. Policy 2020, 15, 295-313. [CrossRef]

20. Ginevičius, R. Multi-criteria assessment of socioeconomic systems' conditions based on hierarchically structured indicator systems. Econom. Soc. 2020, 13, 256-266. [CrossRef] [PubMed] 
21. Androniceanu, A.M.; Kinnunen, J.; Georgescu, I.; Androniceanu, A. A multidimensional approach to competitiveness, innovation and well-being in the EU using canonical correlation analysis. J. Compet. 2020, 12, 5-21. [CrossRef]

22. Pao, H.-T.; Fu, H.C. Renewable energy, non-renewable energy and economic growth in Brazil. Renew. Sustain. Energ. Rev. 2013, 25, 381-392. [CrossRef]

23. Gross, R.; Leach, M.; Bauen, A. Progress in renewable energy. Environ. Int. 2003, 29, 105-122. [CrossRef]

24. Marinaș, M.-C.; Dinu, M.; Socol, A.-G.; Socol, C. Renewable energy consumption and economic growth. Causality relationship in Central and Eastern European countries. PLoS ONE 2018, 13, e0202951. [CrossRef]

25. Belke, A.; Dreger, C.; Dobnik, F. Energy consumption and economic growth-new insights into the cointegration relationship. Energ. Econom. 2010, 33, 782-789. [CrossRef]

26. Zinecker, M.; Skalická, M.; Balcerzak, A.P.; Pietrzak, M.B. Business angels in the Czech Republic: Characteristics and a classification with policy implications. Econ. Res.-Kenosha Istraživanja 2021, 1-26. [CrossRef]

27. Zinecker, M.; Skalická, M.; Balcerzak, A.P.; Pietrzak, M.B. Identifying the impact of external environment on business angel activity. Econ. Res.-Ekonomska Istraživanja 2021, 1-23. [CrossRef]

28. Caruso, G.; Colantonio, E.; Gattone, S.A. Relationships between renewable energy consumption, social factors, and health: A panel vector auto regression analysis of a cluster of 12 EU countries. Sustainability 2020, 12, 2915. [CrossRef]

29. Marra, A.; Colantonio, E. The path to renewable energy consumption in the European Union through drivers and barriers: A panel vector autoregressive approach. Socio-Econ. Plan. Sci. 2021, 76, 100958. [CrossRef]

30. Piekut, M. The consumption of renewable energy sources (RES) by the European Union households between 2004 and 2019. Energies 2021, 14, 5560. [CrossRef]

31. Zinecker, M.; Doubravský, K.; Balcerzak, A.P.; Pietrzak, M.B.; Dohnal, M. The Covid-19 disease and policy response to mitigate the economic impact in the EU: An exploratory study based on qualitative trend analysis. Technol. Econ. Dev. Econ. 2021, 27, 742-762. [CrossRef]

32. Rollnik-Sadowska, E.; Dabrowska, E. Cluster analysis of effectiveness of labour market policy in the European Union. Oeconomia Copernic. 2018, 9, 143-158. [CrossRef]

33. Chocholatá, M.; Furková, A. The analysis of employment rates in the context of spatial connectivity of the EU regions. Equilibrium. Q. J. Econ. Econ. Policy 2018, 13, 181-213. [CrossRef]

34. Lewandowska-Gwarda, K. Female unemployment and its determinants in Poland in 2016 from the spatial perspective. Oeconomia Copernicana 2018, 9, 183-204. [CrossRef]

35. Fragkos, P.; Paroussos, L. Employment creation in EU related to renewables expansion. Appl. Energy 2018, 230, 935-945. [CrossRef]

36. Duscha, V.; Fougeyrollas, A.; Nathani, C.; Pfaff, M.; Ragwitz, M.; Resch, G.; Schade, W.; Breitschopf, B.; Walz, R. Renewable energy deployment in Europe up to 2030 and the aim of a triple dividend. Energy Policy 2016, 95, 314-323. [CrossRef]

37. Comodi, G.; Cioccolanti, L.; Mahkamov, K.; Penlington, R.; Lapuerta, M.; Hernandez, J.J.; Lora, E.E.S.; Venturini, O.; Cobas, V.R.M.; Palacio, J.C.E.; et al. Analysis of labour market needs for engineers with enhanced knowledge in renewable energy in some European and Latin-American Countries. Energy Procedia 2019, 158, 1135-1140. [CrossRef]

38. Pietrzak, M.B.; Balcerzak, A.P.; Gajdos, A.; Arendt, Ł. Entrepreneurial environment at regional level: The case of Polish path towards sustainable socio-economic development. Entrep. Sustain. Issues 2017, 5, 190-203. [CrossRef]

39. Markandya, A.; Arto, I.; Eguino, M.G.; Román, M.V. Towards a green energy economy? Tracking the employment effects of low-carbon technologies in the European Union. Appl. Energy 2016, 179, 1342-1350. [CrossRef]

40. World Bank Group. Poland Energy Transition: The Path to Sustainability in the Electricity and Heating Sector; World Bank: Washington, DC, USA, 2018.

41. Meluzín, T.; Balcerzak, A.P.; Pietrzak, M.B.; Zinecker, M.; Doubravský, K. The impact of rumours related to political and macroeconomic uncertainty on IPO success: Evidence from a qualitative model. Transform. Bus. Econ. 2018, 2017, 148-169.

42. Mamat, R.; Sani, M.S.; Khoerunnisa, F.; Kadarohman, A. Target and demand for renewable energy across 10 ASEAN countries by 2040. Electr. J. 2019, 32, 106670. [CrossRef]

43. Gielen, D.; Boshell, F.; Saygin, D.; Bazilian, M.D.; Wagner, N.; Gorini, R. The role of renewable energy in the global energy transformation. Energy Strategy Rev. 2019, 24, 38-50. [CrossRef]

44. Ma, J.; Oppong, A.; Acheampong, K.N.; Abruquah, L.A. Forecasting renewable energy consumption under zero assumptions. Sustainability 2018, 10, 576. [CrossRef]

45. Farrell, M. EU policy towards other regions: Policy learning in the external promotion of regional integration. J. Eur. Public Policy 2009, 16, 1165-1184. [CrossRef]

46. Scorza, F.; Santopietro, L. A systemic perspective for the sustainable energy and climate action plan (SECAP). Eur. Plan. Stud. 2021. [CrossRef]

47. Musiał, W.; Zioło, M.; Luty, L.; Musiał, K. Energy policy of European Union member states in the context of renewable energy sources development. Energies 2021, 14, 2864. [CrossRef]

48. Aslani, A.; Naaranoja, M.; Helo, P.; Antila, E.; Hiltunen, E. Energy diversification in Finland: Achievements and potential of renewable energy development. Int. J. Sustain. Energy 2013, 32, 504-514. [CrossRef]

49. Seriño, M.N.V. Diversification of nonhydro renewable energy sources in developing countries. Energy Ecol. Environ. 2018, 3, 317-329. [CrossRef] 
50. Xianguo, L. Diversification and localization of energy systems for sustainable development and energy security. Energy Policy 2005, 33, 2237-2243. [CrossRef]

51. Energy Market Agency. Available online: www.are.waw.pl (accessed on 10 November 2021).

52. Pomerania Voivodeship Data. Available online: https://gdansk.stat.gov.pl/dane-o-wojewodztwo/wojewodztwo-1057/warunkinaturalne-i-ochrona-srodowiska (accessed on 10 November 2021).

53. Igliński, B.; Iglińska, A.; Cichosz, M.; Kujawski, W.; Buczkowski, R. Renewable energy production in the Łódzkie Voivodeship. The PEST analysis of the RES in the voivodeship and in Poland. Renew. Sustain. Energy Rev. 2016, 58, 737-750. [CrossRef]

54. Polish Constitution. NS. Of Laws of 1997, No. 78, item 483. Available online: http:/ /isap.sejm.gov.pl/isap.nsf/download.xsp/ WDU19970780483/U/D19970483Lj.pdf (accessed on 15 October 2021).

55. Igliński, B. Badanie Sektora Energii Odnawialnej w Polsce: Potencjał Techniczny, Badania Ankietowe, Analiza SWOT, Analiza PEST; Nicolaus Copernicus University in Torun: Torun, Poland, 2019.

56. Distance Act. NS. Of Laws of 2016, item 961. Available online: https://isap.sejm.gov.pl/isap.nsf/download.xsp/WDU201600009 61/U/D20160961Lj.pdf (accessed on 16 October 2021).

57. RE Act. NS. Of Laws of 2015, item 478. Available online: https:/ /isap.sejm.gov.pl/isap.nsf/download.xsp/WDU20150000478 /U/D20150478Lj.pdf (accessed on 16 October 2021).

58. Polish Energy Strategy. Available online: www.gov.pl/web/klimat/polityka-energetyczna-polski (accessed on 29 September 2021).

59. My Electricity Program. Available online: https:// mojprad.gov.pl (accessed on 24 September 2021).

60. Environmental Law. NS. Of Laws 2001 No. 62, item 627. Available online: https:/ isap.sejm.gov.pl/isap.nsf/download.xsp/ WDU20010620627/U/D20010627Lj.pdf (accessed on 26 September 2021).

61. Central Statistical Office. Quarterly Accounts of Gross Domestic Product in 2016-2020; Warszawa, Poland. 2021. Available online: https:/ / stat.gov.pl/obszary-tematyczne/rachunki-narodowe/kwartalne-rachunki-narodowe (accessed on 10 October 2021).

62. Raw Materials Quotations, Crude Oil. Available online: www.bankier.pl/inwestowanie/profile/quote.html?symbol=ROPA (accessed on 12 October 2021).

63. Coal Price. Available online: www.wnp.pl/gornictwo/notowania/ceny_wegla (accessed on 12 October 2021).

64. Natural Gas Price. Available online: www.bankier.pl/inwestowanie/profile/quote.html?symbol=GAZ-ZIEMNY (accessed on 12 October 2021).

65. Central Statistical Office. Registered Unemployment in the First Quarter of 2021; Warszawa, Poland. 2021. Available online: https:// stat.gov.pl/obszary-tematyczne/rynek-pracy/bezrobocie-rejestrowane (accessed on 13 October 2021).

66. Central Statistical Office. Price Indices of Consumer Goods and Services in April 2021, Warszawa, Poland. 2021. Available online: https:/ / stat.gov.pl/obszary-tematyczne/ceny-handel/wskazniki-cen/wskazniki-cen-towarow-i-uslug-konsumpcyjnychw-kwietniu-2021-roku, 2,114.html (accessed on 14 October 2021).

67. Institute for Renewable Energy. Photovoltaic Market in Poland, Warszawa, Poland. 2021. Available online: https://ieo.pl/pl/ aktualnosci/1538-rynek-fotowoltaiki-w-polsce-2021 (accessed on 14 October 2021).

68. The Energy Law Act of April 10, 1997, Journal of Laws 1997, No. 2017, Item 220. Available online: https:/ /isap.sejm.gov.pl/isap. nsf/download.xsp/WDU19970540348/U/D19970348Lj.pdf (accessed on 22 September 2021).

69. Auction System. Available online: www.ure.gov.pl/pl/urzad/informacje-ogolne/aktualnosci/8739,System-aukcyjny-dlaodnawialnych-zrodel-energii-ma-5-lat.html (accessed on 22 September 2021).

70. National Bank of Poland. Basic Interest Rates. Available online: www.nbp.pl/home.aspx?f=/dzienne/stopy.htm (accessed on 22 September 2021).

71. Central Statistical Office. Demographic Yearbook; Warszawa, Poland. 2020. Available online: https://stat.gov.pl/obszarytematyczne/roczniki-statystyczne/roczniki-statystyczne/rocznik-demograficzny-2021,3,15.html (accessed on 11 October 2021).

72. Coronavirus Information. Available online: https:// koronawirus.abczdrowie.pl (accessed on 12 October 2021).

73. Igliński, B.; Cichosz, M.; Skrzatek, M.; Buczkowski, R. Potencjał techniczny odpadowej biomasy stałej na cele energetyczne w Polsce. Inżynieria Ochr. Sr. 2019, 2, 109-118.

74. Available online: https://podr.pl (accessed on 11 October 2021).

75. Pomorskie Biuro Planowania Regionalnego. Założenia Przestrzenne Rozwoju Odnawialnych Źródet Energii w Województwie Pomorskim; Pomeranian Regional Planning Office: Słupsk, Poland, 2015.

76. Available online: www.mpec.lebork.pl/pl (accessed on 14 September 2021).

77. Agricultural Market Agency. Register of Biofuel and Biocomponent Producers. Available online: www.kowr.gov.pl/uploads/ pliki/DI/Biokomponenty_i_biopaliwa/W/Rejestr_wytworcow_2021.03.26.pdf (accessed on 9 September 2021).

78. The Energy Regulatory Office. Renewable Energy Sources. Available online: www.ure.gov.pl/pl/sekcja/456,Odnawialne-ZrodlaEnergii.html (accessed on 8 September 2021).

79. State Forest Holding. State Forests, Report on the State of Forests in Poland; Warszawa, Poland. 2020. Available online: https:/ / www.lasy.gov.pl/pl/informacje/publikacje/informacje-statystyczne-i-raporty/raport-o-stanie-lasow / raport-olasach-2020.pdf/view (accessed on 14 September 2021).

80. Jasiulewicz, M. Potencjał Biomasy w Polsce; Wydawnictwo Politechniki Koszalińskiej: Koszalin, Poland, 2010. 
81. Central Statistical Office. Statistical Yearbook of Voivodeships; Warszawa, Poland. 2020. Available online: https://stat.gov.pl/ obszary-tematyczne/roczniki-statystyczne/roczniki-statystyczne/rocznik-statystyczny-wojewodztw-2020,4,15.html (accessed on 10 September 2021).

82. Gradziuk, P. Ekonomiczne i ekologiczne aspekty wykorzystania słomy na cele energetyczne w lokalnych systemach grzewczych. Acta Agrophysica 2006, 8, 591-601.

83. Central Statistical Office. Statistical Yearbook of Agriculture 2020; Warszawa, Poland. 2021. Available online: https://stat.gov.pl/ obszary-tematyczne/roczniki-statystyczne/roczniki-statystyczne/rocznik-statystyczny-rolnictwa-2020,6,14.html (accessed on 10 September 2021).

84. Owczuk, M.; Kołodziejczyk, K. Ocena możliwości wykorzystania słomy i wytłoków z lnicznika siewnego jako alternatywnego surowca energetycznego. Chemik 2011, 6, 537-542.

85. Terlikowski, J. Biomasa z trwałych użytków zielonych jako źródło energii odnawialnej. Probl. Inżynierii Rol. 2021, 1, 43-49.

86. Sobczyk, W. Plonowanie wierzby wiciowej-w świetle badań. Polityka Energetyczna 2007, 10, 547-555.

87. Krzyżaniak, M.; Szczukowski, S.; Tworkowski, J.; Stolarski, M.J. Właściwości energetyczne i skład chemiczny biomasy wierzby pozyskiwanej z systemu Eko-Salix. Zesz. Probl. Postępów Nauk. Rol. 2015, 581, 21-28.

88. Igliński, B.; Iglińska, A.; Kujawski, W.; Buczkowski, R.; Cichosz, M. Bioenergy in Poland. Renew. Sustain. Energy Rev. 2011, 6, 2999-3007. [CrossRef]

89. Central Statistical Office. Environmental Protection 2020; Warszawa, Poland. 2020. Available online: https://stat.gov.pl/obszarytematyczne/srodowisko-energia/srodowisko/ochrona-srodowiska-2020,1,21.html (accessed on 11 September 2021).

90. Haynes, W.M. (Ed.) CRC Handbook of Chemistry and Physics, 97th ed.; CRC Press: Boca Raton, FL, USA, 2016.

91. Polish Wind Energy Association. Onshore Wind Energy in Poland TPA Poland; 2021. Available online: http://psew.pl/wpcontent/uploads/2021/05/Raport_Ladowa-energetyka-wiatrowa-w-Polsce_2021-05-11.pdf (accessed on 12 September 2021).

92. Meteorological Materials Obtained from the Institute of Meteorology and Water Management, Warsaw (Excel Files).

93. Offshore in Poland. Available online: www.mir.gov.pl/Gospodarka_Morska/Pozwolenia/Documents/Mapa_potencjalnych_ miejsc_farmy_wiatrowe.pdf (accessed on 2 October 2021).

94. Polish Wind Association Data. Available online: http://psew.pl/pge-i-orsted-podpisaly-umowe-o-utworzeniu-joint-venture-wzakresie-budowy-farm-wiatrowych-na-baltyku (accessed on 3 October 2021).

95. The State Water Holding Polish Waters. Available online: www.kzgw.gov.pl (accessed on 4 October 2021).

96. Central Statistical Office. Transport. Maritime Economy; Szczecin, Poland; 2020. Available online: https://stat.gov.pl/obszarytematyczne/transport-i-lacznosc/transport/gospodarka-morska-w-polsce-w-2020-roku,7,18.html (accessed on 4 October 2021).

97. Polish Geological Institute Data. Available online: www.pgi.gov.pl/dane-geologiczne/geologiczne-bazy-danych.html (accessed on 18 September 2021).

98. Central Statistical Office in Gdańsk. Tourism in the Pomerania Voivodeship in 2020; Gdańsk, Poland. 2021. Available online: https://gdansk.stat.gov.pl/opracowania-biezace/opracowania-sygnalne/sport-turystyka/turystyka-w-wojewodztwiepomorskim-w-2020-r-, 5,14.html (accessed on 5 October 2021).

99. Sejmik of the Pomerania Voivodeship. Pomerania Voivodeship Development Strategy 2030; Gdańsk, Poland. 2021. Available online: https://pomorskie.eu/wp-content/uploads/2021/04/Za\%C5\%82\%C4\%85cznik-do-uchwa\%C5\%82y_SWP_376_XXXI_ 21_SRWP2030_120421.pdf (accessed on 6 October 2021).

100. Central Statistical Office. Fuel and Energy Consumption in 2019, Warszawa, Poland. 2020. Available online: https://stat.gov.pl/ obszary-tematyczne/srodowisko-energia/energia/ zuzycie-paliw-i-nosnikow-energii-w-2019-roku,6,14.html (accessed on 6 October 2021). 